\title{
The Politics of Dignity: How Status Inequality shaped Redistributive Politics in India
}

\author{
Poulomi Chakrabarti* \\ Prepared for American Political Science Association Annual Meeting
}

September 12, 2020

\begin{abstract}
Conventional theories of the welfare state are premised on the interests of social classes - the wealthy elite oppose redistribution, while the working class supports expansive social rights. I argue that in multiethnic societies with long histories of discrimination, ethnic groups are motivated by concerns of enhancing their material well-being as well as their social status. Political elites from dominant groups are more likely to oppose redistributive policies, but unlike the working class, the policy preference of marginal groups is mediated by the level of status inequality. Under conditions of high inequality, which is indicative of discrimination and humiliation faced by members of marginal groups, concerns of dignity find precedence over pure redistribute policies. The politics of dignity is most concretely manifested through demands for symbolic and descriptive representation. Greater representation of marginal groups in the bureaucracy can be instrumental in transforming the structural conditions that generate demand for redistribution. I demonstrate this in the context of India by examining the caste identity of legislators, patterns in public spending and historical accounts of demands by lower caste mobilizations in major states over five decades.
\end{abstract}

*Assistant Professor of Political Science, Queen's University. Email: pdc@queensu.ca. 
Theories of political behavior are based on the claim that social classes are characterized by welldefined interests as reflected in their preference for redistribution - the wealthy elite oppose political rights because of its redistributive effects, while the working class supports expansive political and social rights (Acemoglu and Robinson 2006; Boix 2003; Esping-Andersen 1990; Rueschemeyer, Huber, and Stephens 1992). The role of class-coalitions is arguably the most dominant strand of inquiry in the literature on the welfare state and democratization. The effects of group-based social coalitions on redistribution, however, remain largely unexplored. If we were to categorize ethnic groups as dominant or marginal, as is often the case in many multiethnic countries, would these groups mimic the political preferences of social classes? Should we expect dominant groups to oppose taxation and marginal groups to support redistribution? What does redistribution in multiethnic societies depend on?

This article examines these questions by examining the role of status inequality in shaping the nature of redistributive politics in hierarchical societies. Status is based on widely shared beliefs about the innate differences in the ability and worth of different groups, which reinforces economic inequality between groups. Redistributive policy in hierarchical societies is hence not just directed at economic inequality but faces the additional burden of dismantling status beliefs. Representation is important to the policy agenda such societies because it is one of the means reduce institutional and psychological discrimination. Greater representation of marginal groups in the state bureaucracy can further be instrumental in transforming the structural conditions that generate demand for redistribution.

In contrast to pure social classes, I argue that ethnic groups are motivated by concerns of enhancing their material well-being as well as their social status. Political elites from dominant groups are more likely to oppose redistributive policies and measures for status equalization in order to preserve their social position. Their policy preferences are hence likely to be similar to those of the economic elite. Unlike the working classes, however, economic redistribution is not the main or the only goal of marginal groups. I argue that the policy preference of marginal groups is mediated by the level of status inequality. Under conditions of high inequality, which is indicative of discrimination and humiliation faced by members of marginal groups, concerns of recognition find precedence over pure redistribute policies. I refer to mobilization by marginal groups aimed at equalization of status hierarchy as the 
politics of dignity. The politics of dignity is most concretely manifested through demands for symbolic and descriptive representation in the state.

I test this theory through the case of India, arguably one of the most ethnically diverse democracies with a long history of caste-based discrimination. Specifically, I examine how the caste identity of legislators and caste-based inequality shaped patterns in public spending in all major states over five decades. I find that upper caste representation is consistently associated with lower support for redistribution and caste inequality is a stronger predictor of redistribution than income inequality. The policy preferences for marginal castes, however, varies by group. I examine two groups - lower castes, including Dalits (former "untouchable" caste) who are guaranteed legislative quotas, and backward castes, who do not benefit from legislative quotas but enjoy reservation in public employment to varying degrees across states.

In line with existing studies, I find that lower caste representation is not associated with redistributive spending, suggesting that in the absence of strong Dalit mobilization, their policy preferences are likely to be diluted by the agenda of the parties that they are part represent (Ahuja 2019; Jensenius 2017). Contrary to expectation, backward caste support for redistribution increases at higher levels of representation. Further, combined with administrative reservations, their prioritization of social spending rises. This study employs the largest panel on legislator identity and caste-based reservations in public employment at the state level in India. Though the argument developed here is based on insights from India, it has implications for other hierarchical societies, especially where political mobilization by marginal groups has assumed political power. This research contributes towards our understanding of welfare state and public goods provision in multiethnic societies.

\section{STATUS INEQUALITY AND REDISTRIBUTION}

Much of the literature on redistributive politics is based on the policy preferences of social classes (Acemoglu and Robinson 2006; Boix 2003; Esping-Andersen 1990; Rueschemeyer, Huber, and Stephens 1992). Societies with long histories of group-based discrimination owing to legacies of caste, slavery, colonialism or apartheid are not just stratified by class but also by status. Such societies, that Horowitz (1970) refers as "ranked ethnic systems", are marked by clearly understood conceptions of 
superordinate and subordinate groups. Ridgeway $(2019,1)$ defines status as "a comparative social ranking of people, groups, or objects in terms of social esteem, honor, and respect accorded to them". The idea of status goes back to Weber's conceptualization of inequality, which he argued is based on three interrelated but distinct sources: resources, power, and status (Weber 1978). Status inequality captures differences in honor, prestige and respect. As opposed to resources and power, however, status inequality has received less attention in the social sciences because it is not seen as an independent mechanism that can generate inequality (Ridgeway 2014).

There have been some remarkable exceptions in recent years (Cramer 2016; Suryanarayan 2018; Acharya, Blackwell, and Sen 2016; Mutz 2018). By focusing on the political behavior of high-statuspoor individuals, these studies are able to decouple status from other material endowments and hence convincingly demonstrate the independent effects of status on political and economic outcomes. The cases they examine are, however, exceptions. In most societies, economic wellbeing coincides with status hierarchy. Blacks in the United States and South Africa are disproportionately poor. Lower caste groups in India, on average, are at the bottom of the economic hierarchy. This overlap between material and status privilege is not a coincidence. Historically, the division of labor was institutionalized through say the slavery and the caste system. But even after formal legislations dismantled these institutions, the beliefs that legitimized these hierarchies continue to endure.

Status is based on widely shared beliefs about the innate differences in the ability and worth of different categories of people. These beliefs, like theories of racial difference, patriarchy and civilizational progress, dictate social relations. In the process, they reinforce inequality between groups through three distinct ways. One, status beliefs shape societal perceptions of competence of different groups, thus providing an implicit intellectual justification for discrimination. Two, they operate at a socialpsychological level by shaping an individual's own expectations of self-worth, which in turn effects their behavior. ${ }^{1}$ Finally, the bias generated by status beliefs shapes social networks - who people form ties with and favor for exchange of information, opportunities, and affection (Ridgeway 2014). Over the

\footnotetext{
${ }^{1}$ Field experiments in India find that publicly revealing the caste of middle school boys reduces the performance of lower caste individuals (Hoff and Pandey 2006). Sniderman and Piazza (1993) surprisingly find that Black Americans generally endorse unfavorable stereotypes of their group as "lazy, irresponsible, and violent" even more strongly than Whites.
} 
long term, the cumulative effects of discrimination, notions of self-worth, and narrow social networks leads to the accumulation of power and resources and sustains group-based inequality (Ridgeway 2014). Though relatively novel in political science, a long line of research in social psychology has examined how status beliefs contribute towards the stability of exploitative social systems (Jackman 1994; Jost, Banaji, and Nosek 2004; Sidanius and Pratto 1999).

In hierarchical societies, ethnic groups can hence be broadly categorized into two types: dominant groups, distinguished by ascriptive privilege, and marginal groups that rank lower in status hierarchy. Traditionally, status is enforced through an "elaborate set of behavioral prescriptions and prohibitions" which dictate the occupation, diet, dress, and religious practices, and norms of interaction of groups (Horowitz 1970, 24). These norms serve as a tool to dehumanize and humiliate marginal groups and, in the process, internalize hierarchy in the minds of members of both the dominant and marginal groups. Humiliation continues to mark the social relations between groups long after formal institutions like slavery, apartheid and untouchability that legitimized these practices are abolished. Members of dominant groups are generally wealthier and marginal groups are likely to be poor. But more importantly, members of marginal groups are likely to have experienced humiliation, despite their social class. Barack Obama, for example, has written about being subject to racism, even as a US senator, "I can recite the usual litany of petty slights that during my 45 years have been directed my way: security guards tailing me as I shop in department stores, white couples who toss me their car keys as I stand outside a restaurant waiting for the valet, police cars pulling me over for no apparent reason." (Obama 2006, 233). Meira Kumar, the former Speaker of the Lower House in the Indian Parliament, noted that she continued to be served in separate utensils (a remnant of the practice of untouchability) when invited to upper caste homes (Jensenius 2017). The experience of humiliation and discrimination is distinct from material deprivation and has implications for redistributive politics in hierarchical societies.

\section{Status Inequality and Political Mobilization}

Status inequality influences political mobilization through three main ways: i) it shapes the behavior of the political elite, ii) it motivates voting decisions, and iii), it influences the policy agenda of marginal groups. Qualitative accounts of ethnic parties and social movements consistently find that elite from 
marginal groups are often motivated to organize politically due to personal experiences of humiliation. Before Gandhi led the Independence movement in India, for example, he campaigned for civil rights in South Africa for more than two decades. As a young lawyer, Gandhi was thrown out of a first-class train compartment, which at the time did not allow non-Europeans. He spent the night in the waiting room in the Pietermaritzburg station. Gandhi describes the incident in his autobiography, "My overcoat was in my luggage, but I did not dare to ask for it lest I should be insulted again, so I sat and shivered" (Gandhi 1983, 209). Experiences of racial prejudice bothered him deeply and pushed him to protest discriminatory laws. A plaque on the platform in Pietermaritzburg reads, "This incident changed the course of his life."

Discrimination can play an instrumental role in mobilization even in case where state policies are redistributive. In Bolivia, for example, Van Cott $(2005,64)$ finds that indigenous movements broke away from the left and established ethnic parties because their leaders had grown frustrated with the "interference, manipulation, deceit, and racism" in those alliances. Chandra (2004) argues that ethnic elites choose parties that provide the most incentives for advancement in its organizational ranks. Lower caste leaders in India formed their own parties in states where they faced a glass-ceiling in mainstream parties (Chandra 2004; Jaffrelot 2003).

Discrimination also shapes voting behavior. Rather than examining policy platforms or ideological positions, Chandra (2004) argues that voters choose parties that represent the highest number of candidates from their ethnic group. These ethnic preferences are based on the underlying belief that having their "own" in the state is likely to improve their chances of accessing state benefits and the ethnic "other" is likely to discriminate against them. At the individual level, voters exposed to greater discrimination place a higher value on descriptive representation, even when such representation provides few material benefits (Malik 2019). The threat of losing social status, on the other hand, can even lead to members of dominant groups to vote against their material interests (Suryanarayan 2018; Mutz 2018).

Besides electoral behavior, status inequality also shapes the political ideology and the policy agenda in hierarchical societies. A class-based understanding of social justice is based on equality of opportunity, regardless of an individual's material endowment. Hence it focuses on redistribution, especially public 
education and universal healthcare. An identity-based idea of justice aims for equalization of status across groups. It faces the additional burden of dismantling status beliefs and bias, both institutional and psychological. In contrast to the politics of redistribution that is directed at economic injustice, Fraser (1995) argues that identity-based mobilizations seek to remedy cultural domination, nonrecognition and disrespect by transforming social patterns of representation. This may involve demands for equal treatment before the law, as noted by the civil rights movement and mobilization by feminist and LGBTQ groups, group-based affirmative action like targeted social programs and guaranteed political representation, and measures that recognize the cultural distinctiveness of minorities. These policies may not get reflected in conventional measures of economic redistribution. This research primarily focuses on the policy agenda of marginal groups.

\section{The Politics of Dignity and Redistribution}

In contrast to pure social classes, ethnic groups are motivated by concerns of enhancing their material well-being as well as their social status. Mobilization by dominant groups like Ku Klux Klan against African Americans or upper castes against lower castes in India, for example, aim at preserving their status. This may translate to supporting segregationist policies or restricting access of lower caste groups to temples. I broadly construe such mobilizations as the politics of dominance. Mobilization by marginal groups, on the other hand, is motivated to fight prejudice and domination. Ethnic subordination as a means of organizing social relations lost its legitimacy with the spread of liberalism and norms of equality in the $20^{\text {th }}$ century. With it, the idea of dignity has replaced traditional norms of honor (Taylor 1994). Dignity is based on the premise that all humans are equally worthy of respect. Movements by African Americans, black and colored South Africans, indigenous communities in Bolivia, and lower castes in India have focused on recognition and representational claims. I refer to mobilization by marginal groups aimed at equalization of status hierarchy as the politics of dignity.

Identity-based social movements can play an important role in placing new issues on the political agenda, but they are most likely to influence policy outcomes when mobilization by marginal groups results in political power. Drawing on our understanding of the welfare state as well as ethnic politics, I argue that redistribution in hierarchical societies is shaped by the interaction of two factors: i) the identity of political elite, and ii) the level of status inequality at the time when the political elite assume 
power. Political elites from dominant groups are more likely to oppose redistributive policies and measures for status equalization in order to preserve their social position. Given that dominant groups are more likely to control the means of production, we can expect their policy preferences to be similar to that of the economic elite.

Unlike the working classes, however, economic redistribution is not the main or the only goal of marginal groups. I argue that the policy preference of marginal groups is mediated by the level of status inequality. Under conditions of high inequality, which is indicative of discrimination and humiliation faced by members of marginal groups, concerns of dignity and recognition find precedence over pure redistribute policies. Though there may be several avenues for equalization of status, the politics of dignity is most concretely manifested through demand for representation. Representational claims on the state are particularly important so that marginal groups are reflected in institutions of power and seen as legitimate members of the political community. These claims take two forms - symbolic and descriptive.

\section{Figure 1: Examples of Symbolic Representation}

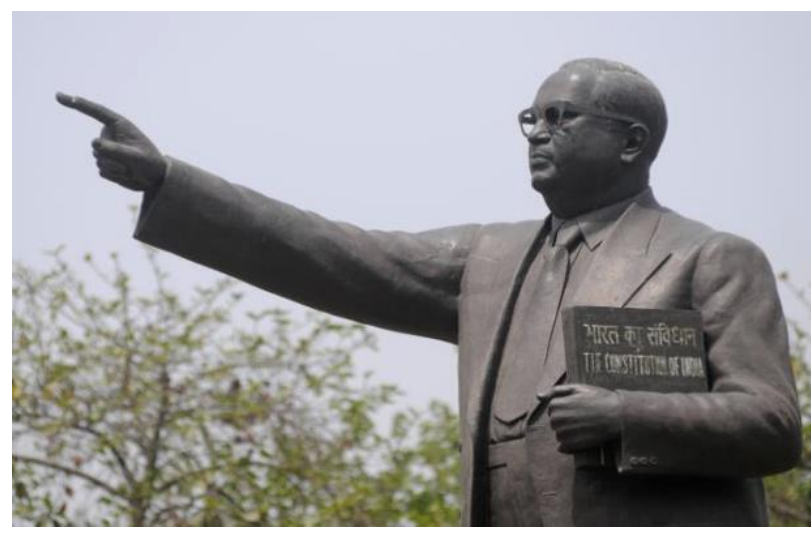

1a: Statue of B R Ambedkar, Parliament House, New Delhi.

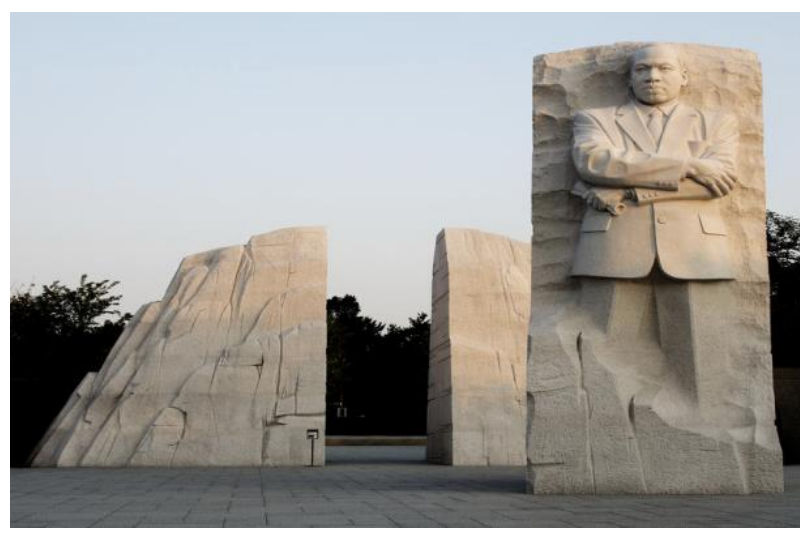

1b. The Stone of Hope, Martin Luther King Jr. Memorial, Washington DC.

Symbolic representation refers to revaluing marginalized identities in the public sphere by acknowledging their achievements and struggles. It may include naming or renaming streets and public parks after leaders of marginal groups, and publicly recognizing their cultural practices, languages, and histories. Examples of symbolic representation include the statue of Ambedkar, India's most prominent lower caste leader and the principal architect of its Constitution, in the Indian Parliament 
or the memorial dedicated to Martin Luther King Jr. at the National Mall in Washington DC (Figure 1). The removal of symbols of majority domination - for example taking down confederate monuments in the American South because of the belief that they glorify white supremacy, can also be conceived as symbolic representation.

Descriptive Representation refers to the extent to which representatives resemble the identity of those being represented, based on say gender, ethnicity or sexuality (Pitkin 1967). Representation finds support from political theorists who argue that the nature of deliberation on policy issues should benefit from the shared experience of members of disadvantaged groups (Mansbridge 1999). As evident from the Black Lives Matter movement in recent years, representation of minorities in the law enforcement is especially important in cases where state repression by the dominant group is used as a means of social control (Gourevitch 2015; Soss and Weaver 2017).

Representation is central to the policy agenda of the politics of dignity because it is one of the important means to reduce institutional and psychological discrimination. Minority representation in elected bodies, for example, can reduce discrimination by changing social and legal norms of interaction between groups (Chauchard 2014), alter stereotypes about the ability of minorities to assume leadership roles (Jensenius 2017), and can increase overall support for minority leaders by reducing racial threat (Hajnal 2001). These findings echo theories of social change in social psychologists who emphasize the role of greater contact between groups in humanizing the "other" and extending the moral circle of our solidarity (Bloom 2010; Paluck, Green, and Green 2019). The marginal becomes mainstream through its representation in the public sphere. Within the context of the state, greater representation of marginal groups in the bureaucracy can reduce discrimination in policy design and implementation and breakdown elite patronage networks at the local level. Descriptive representation can be instrumental in transforming the structural conditions that generate demand for redistribution. 


\section{EMPIRICAL STRATEGY}

\section{Lower Caste Political Mobilization in India}

The caste system divides the Hindu society into endogamous occupational groups in the following hierarchical order: Brahmins (priests), Kashatriya (warriors), Vaishyas (merchants), Shudras (workers), and Dalits or Scheduled Castes (SC) and indigenous groups or Scheduled Tribes (ST). ${ }^{2}$ The broad caste categories or varnas further comprise of hundreds of jatis or sub-castes that typically refer to hereditary occupations. Caste is traditionally based on ideas of ritual purity and pollution. The first three groups are known as Forward castes, which implies that access to sacred texts is restricted to them. Dalits were considered untouchable because they engaged in "polluting" occupations. Like other forms of social hierarchy, caste was characterized by segregation and humiliating practices of deference. Ambedkar described the system as an "ascending scale of reverence and a descending scale of contempt." (Jaffrelot 2003). Caste hierarchy was traditionally justified by an elaborate ideology based on the moral balance of an individual's action in previous lives - those born into lower castes were being punished for their sins in their past lives. Hence societal inequality was believed to be a reflection of spiritual merit accumulated across past existence. The gradual breakdown of this ideology removed the self-imposed moral barrier by lower caste groups to challenge social hierarchy (Weiner 2001; Galanter 1984).

From the late $19^{\text {th }}$ century onwards, lower caste groups have politically mobilized to fight caste-based oppression. Due to structural reasons, states in South India were better positioned for such movements - forward castes formed a smaller share of the population and more egalitarian land tenure systems did not allow them to have absolute control over economic resources as compared to their counterparts in the Hindi-heartland in the North (Jaffrelot 2003; Varshney 2000; A. Banerjee and Iyer 2005). The state legislature in Madras Presidency, for example, was already two-third nonBrahmin in the 1935 provincial elections (Baker 1976). The North, in contrast, faced stronger resistance from the upper caste groups. In states like Uttar Pradesh, for example, they represent almost a fourth of the population (see Annex A). The landlord-based zamindari system in most northern states further

\footnotetext{
2 Though caste traces its origins to Hinduism, other religious groups in South Asia are also stratified along caste lines.
} 
limited the economic independence of lower castes. The politics of these states has been described as "vertical mobilization" - lower castes were tied to upper castes through clientelistic networks (Rudolph and Rudolph 1984).

The Indian state took measures to reduce caste oppression after Independence, in large part due to the efforts of Ambedkar. Untouchability was abolished in 1950. The state mandated political representation for SCs and STs at both the federal and state levels, making it most extensive and longest-standing identity-based affirmative action program in the world (Jensenius 2017). But it wasn't until the early nineties that mobilization by lower castes made a serious dent in North India. A number of factors contributed towards the economic and political empowerment of lower castes - land reforms, including abolition of zamindari system, green revolution and the subsequent commercialization of agriculture benefited peasant castes (Weiner 2001; Dasgupta 2018), and castebased quotas in public employment benefited sections of Dalits (Chandra 2004; Jaffrelot 2003). In what has been described as the "silent revolution" (Jaffrelot 2003) and "India's second democratic upsurge" ${ }^{3}$ (Yadav 2000), the parliament and legislatures in most states had begun to resemble the caste identity of the population by the turn of the $21^{\text {st }}$ century (Jaffrelot and Kumar 2009).

This political revolution has been largely led by the Shudras. This heterogenous group of "middle" castes make up about half the population and include the politically salient Other Backward Classes (OBCs), an administrative category of sub-castes that are eligible for affirmative action. Shudras include the prosperous landowning castes, called "dominant castes" that are not ritualistically high in the caste hierarchy, but dominate the economic life in many regions (Srinivas 1995). At the other end of the spectrum, they include service castes, like potters and weavers, who did not suffer from untouchability but their economic condition is closer to that of Dalits. Most Shudras are peasants. The distinction between Shudras and Dalits is relevant because they present considerable variation in their economic condition and relationship to the state. Dalits have historically endured the most severe forms of social exclusion and continue to remain at the bottom of the economic hierarchy (S. Desai and Dubey 2011). They have however benefited from legislative reservations at the federal, state and local levels. In

\footnotetext{
3 The sixties was conceptualized as the "first democratic upsurge" when voter turnouts soared and a number of parties emerged as serious alternatives to the one-party dominance of the Congress (Yadav 2000).
} 
contrast, due to their numeric advantage it was believed that Shudras would be able to mobilize under universal franchise and did not need electoral quotas. Hence while Dalit representation in the legislatures is largely a result of state mandate, Shudra representation reflects the strength of its political mobilization. Elections in reserved constituencies are almost as competitive as other areas (Jensenius 2017), but with the exception of the Dalit-led Bahujan Samaj Party (BSP) that has been successful in the state of Uttar Pradesh, most parties are controlled by non-SC politicians. In contrast, a large number of parties are led by Shudras.

The conditions for political mobilization by Shudras was generated by economic mobility - some peasant castes like Yadavs and Koeris experienced substantial gains in income due to the green revolution (Weiner 2001; Dasgupta 2018) and the share of Shudras in the small businesses sector rose to their population share after the economy liberalized (Iyer, Khanna, and Varshney 2013). This mobilization consolidated around "OBC politics" in the early nineties (Yadav 2000). The term OBC traces its roots to the Madras presidency in the 1870s. The British administration combined Shudras and Untouchable castes under the label "backward classes" as a means to identify non-Brahmins for positive discrimination. Untouchables were reclassified as Scheduled Caste in the 1935 Government of India Act. After Independence, the Indian government continued to use this classification for extending affirmative action (Jaffrelot 2003). The constitution had also resolved to make provisions for non-SC lower castes. Two federal-level Backward Classes Commissions were appointed in 1953 and 1978 respectively. Congress-led governments, however, disregarded the recommendations for OBC reservations made by both reports. This allowed the otherwise fragmented Shudra sub-castes to galvanize around demands for $\mathrm{OBC}$ quotas in public employment and higher education. The Janata Party-led government implemented the recommendations of the second commission, led by B.P. Mandal, months after it assumed power in 1989. This led to massive protests by upper caste students throughout North India. The counter-mobilization by lower castes transformed "OBC" from abstract administrative category into a politically salient group (Jaffrelot 2003). Yadav (2000) argues that the rise in electoral participation in the nineties coincides with the "Mandalization" of politics. 


\section{Conceptualizing and Measuring Caste Coalitions and Status Inequality}

I conceptualize caste coalitions to reflect the rank-ritual as well economic hierarchy of social groups. In order to reflect the internal differences within the non-forward castes, I classify social groups into three broad caste coalitions: i) Upper Caste, that includes Forward and Dominant caste groups from all religions, ii) Backward Castes, including both peasant and service caste Shudras, and iii) Lower Castes, which includes SCs and STs, again from all religions (Figure 3. See Annex B for coding protocol).

Figure 2: Structure of Caste Hierarchy

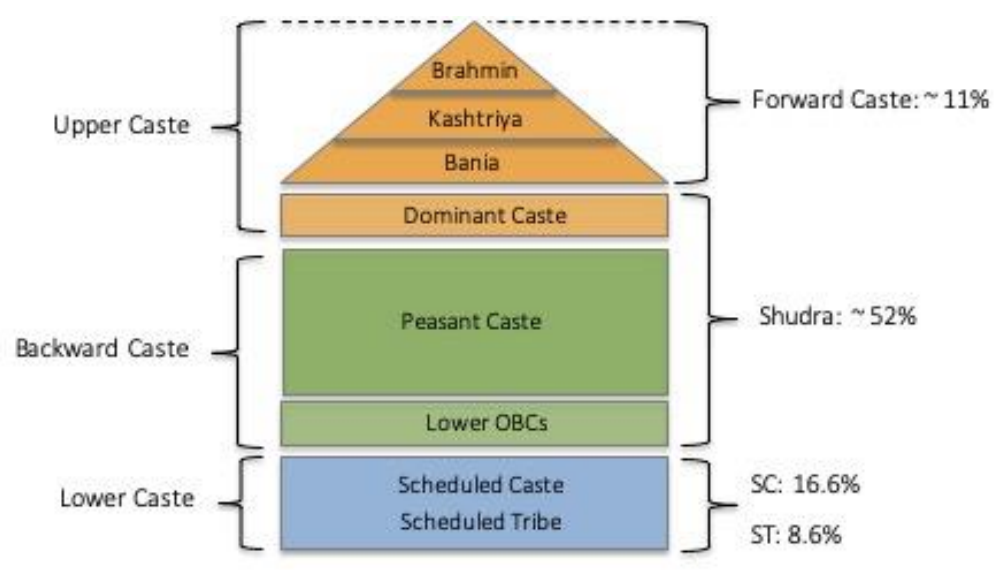

I examine the identity of the political elite through the caste and religious background of state-level legislators, originally collected by the authors of the edited volume Rise of the Plebeians?: The Changing Face of Indian Legislative Assemblies (Jaffrelot and Kumar 2009). One of the advantages of using the original datasets is that it includes information on jatis, which is the narrowest ethnic identity salient in political mobilization in India. This allows me to capture the vast heterogeneity within the Shudras. The dataset also includes information on legislator's party affiliation, and in some states, whether the legislator had held a party office, which can be used to identify legislators in the ruling coalition and influential politicians respectively. Though information for some state-years is missing, this dataset covers elections in sixteen major states from 1955 to 2009 (see Annex B).

Information on parties that formed the government was gathered from various secondary sources. I account for the caste distribution of the population through estimates from the National Election Studies (NES), based on the survey round in which the proportion of SC and ST most closely matched 
the actual population estimates of the 2011 Census. ${ }^{4}$ The NES presents a high correlation (ranging between 0.94 to 1.0) with the census data on caste and religion, making it a more reliable measure than available alternatives (see Table A2). ${ }^{5}$ Consistent with the existing literature, I assume that the caste distribution of states has remained relatively stable over time (A. Banerjee and Somanathan 2007; Suryanarayan 2018).

I construct measures for representation of political elite in three institutions - i) the state legislature, i.e. all Members of Legislative Assembly (MLAs), ii) state government, i.e. MLAs in the ruling coalition, and iii) MLAs that hold an important office in parties. Representation of a caste $y$ in a particular institution is calculated as the ratio of the proportion of MLAs from that group in that institution in state $i$ at year $t$ to the proportion of the caste in the respective state population. A value of more than 1 indicates that the particular caste group is overrepresented (see Figure B2).

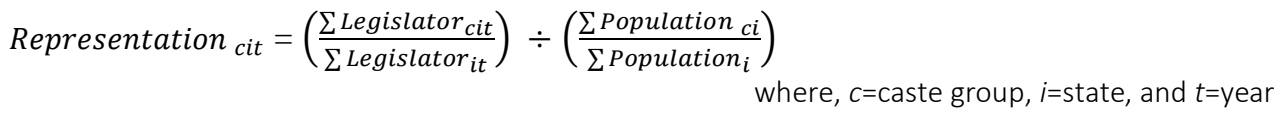

Figure 3: Distribution of Caste-based Representation in state legislatures by decade

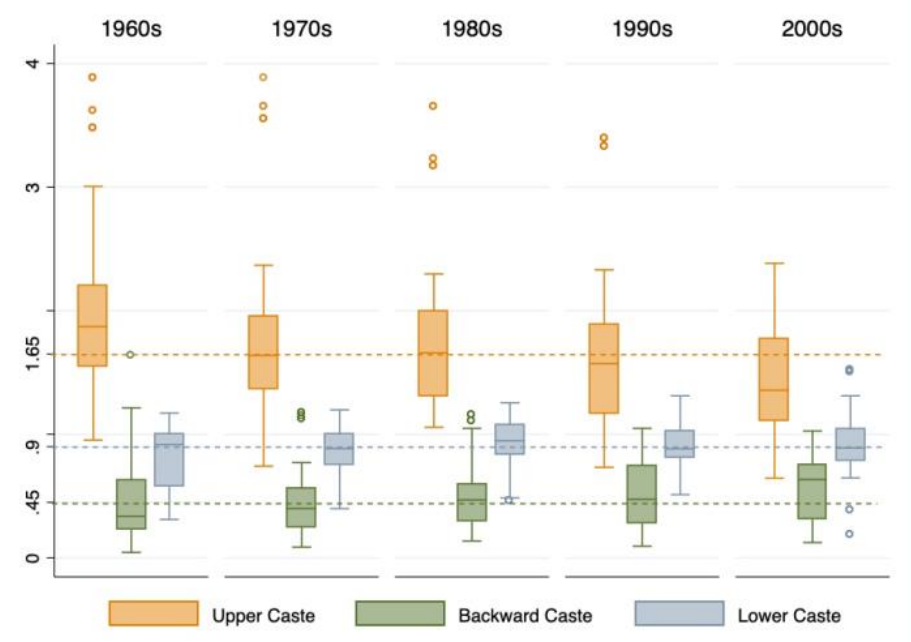

\footnotetext{
${ }^{4}$ NES surveys are based on random sampling immediately after state elections to capture voting patterns and gauge public opinion on a host of issues.

${ }^{5}$ Some researchers have used district-level estimates of the 1931 caste census, which was the last time that a caste census was carried out for which data is available (A. Banerjee and Somanathan 2007; Suryanarayan 2018). Using the 1931 data to estimate the current caste structure is likely to generate errors not only because they are almost a century old, but also because district boundaries have changed many times in the last eight decades.
} 
While upper castes remain overrepresented in state legislatures (median 1.65), their numbers have steadily declined in the last five decades. Lower castes include non-Hindu lower castes who do not qualify for legislative reservations. SC and lower caste representation have remained relatively stable over time, with median values of 1.0 and 0.93 respectively. Backward castes show the greatest variation, with median representation increasing from 0.34 in the 1960 s to 0.64 in 2000 s (see Annex B).

Status Inequality

Status inequality, as discussed earlier, refers to difference in ascriptive social status across groups. As compared to income inequality, it is difficult, if not impossible, to construct a measure of humiliation that can truly capture the variation in caste-relations across time and regions. Currently no nationwide survey of caste-based discrimination exists and only a handful of nationally representative surveys collect data on all major caste groups. But given the highly interconnected nature of social and economic life in India, we should expect a high degree of correlation between material and status inequality. ${ }^{6}$ I use income and class as a proxy for status to generate two measures caste inequality.

A number of studies have examined differences in group-based income through the Between Group Inequality index (Huber and Suryanarayan 2016; Baldwin and Huber 2010; Houle, Kenny, and Park 2019). BGI utilizes the principles of the Gini index but is based on group's mean income instead. It is interpreted as the expected difference in the mean income of the groups of any two randomly selected individuals. $\mathrm{BGI}$ ranges from 0 to 1 - the larger the $\mathrm{BGI}$, the higher the correlation between group identity and income. The formula for BGI is:

$$
B G I=\frac{1}{2 \bar{y}} \sum_{m=1}^{k} \sum_{n=1}^{k} p_{m} p_{n}\left|\bar{y}_{m}-\bar{y}_{n}\right|
$$

where $\mathrm{m}$ and $\mathrm{n}$ index groups, $p_{m}$ is the proportion of the population in group $\mathrm{m}, \bar{y}_{m}$ is the average income of group $\mathrm{m}, \bar{y}$ is the average income in the society, and $\mathrm{k}$ is the number of groups in the society. I rely on income data disaggregated by caste based on the India Human Development Survey (IHDS).

\footnotetext{
${ }^{6}$ For a discussion of measuring caste-based inequality, see (Chakrabarti 2020).
} 
The second measure of status inequality relies on the distribution of caste and class, relying on the assumption that the extent to which lower caste groups have broken the class barrier should reflect equalization of social hierarchy. For example, in Bihar, only $6 \%$ of the lower caste can be considered upper class, as compared to $12 \%$ backward castes and 30\% upper castes. In Kerala, in contrast, the proportions for lower, backward and upper castes are 36\%, 37\% and 50\% respectively. These figures seem consistent with secondary sources - Bihar is generally regarded as one of the most unequal states, while Kerala is often cited as an example of egalitarian social relations in India (Witsoe 2013; Heller 2000).

I use occupation and educational attainment to measure social class, based on NES state-level surveys (see Annex B for coding protocol). The use of occupation is an improvement over income-based measures that tend to be less reliable in household surveys in India. It also allows me to account for differences in lifestyles and amenities across rural and urban areas that asset-based measures tend to conflate. I measure caste-based inequality through the caste distribution of the upper class, given by the following formula. A larger number should indicate greater dominance of upper castes.

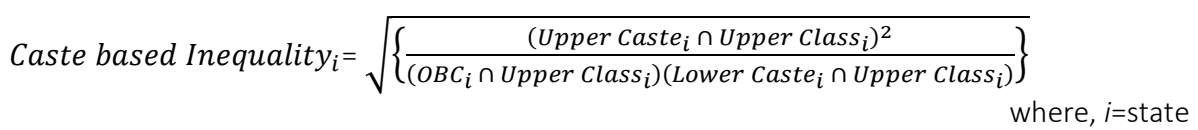

These measures more appropriate than available alternatives since it accounts for all major caste groups. ${ }^{7}$ I use the second measure in the main models for several reasons. As discussed earlier, the use of occupation is more reliable than income-based measures. Second, NES data is a more accurate representation of actual population estimates as compared to IHDS (correlation of .95 versus .85; see Annex A). Third, using NES data allows me to follow a consistent categorization of caste groups across multiple types of data. While SCs is well-defined, population estimates for OBCs vary widely across surveys (see Annex A).

\footnotetext{
${ }^{7}$ Recent studies that have explored caste-based exclusion have focused only on SCs (Thorat and Joshi 2015; Girard 2018). Suryanarayan (2018) relies on data on overrepresentation of Brahmins among the literate population from the 1931 census to explore the legacy of Brahmin dominance on contemporary voting.
} 


\section{Dependent Variable: Redistribution}

I measure redistribution as the proportion of developmental spending dedicated to social sectors. More than fifty years of State-level budget reports collected from the Reserve Bank of India (RBI) archives were digitized (see Annex B). The use of public spending to measure social development is consistent with the existing literature on the welfare state (Esping-Andersen 1990; E. Huber, Ragin, and Stephens 1993) as well as development in India (A. Banerjee and lyer 2005; P. Chhibber and Nooruddin 2004; Keefer and Khemani 2003; Ravallion and Datt 2002; Singh 2016). However, I make two departures. First, I draw a distinction between state capacity and the policy priority of the state. State capacity, or the bureaucratic ability to implement state policy, is independent of the normative goals of the state (Centeno et al. 2017; Berwick and Christia 2018). High capacity states are more effective in administering redistributive as well as growth-oriented policies as compared to states that lack the ability to implement even their most basic mandated programs. The per capita developmental spending in Bihar in 2012, for example, was almost a third of Tamil Nadu, though their proportional spending in social sectors was comparable. The use of proportional, rather than absolute spending, is hence a more accurate reflection of the political will of state elite to prioritize redistribution. Second, as opposed to most existing studies that use performance in health and education (A. Banerjee and Iyer 2005; Keefer and Khemani 2003; Singh 2016), I rely on the entire gamut of the state's development expenditure. Spending in health and education, though a reliable proxy for redistribution, account for less than a fifth of overall social spending in India. ${ }^{8}$ (see Figure B1).

$$
\text { Preference for Redistribution }_{i t}=\left(\frac{\text { Social Sector Spending }_{i t}}{\text { Developmental Spending }_{i t}}\right)
$$

where, $i=$ state, and $t=$ year

\section{Alternative Explanations and other Controls}

A large body of work has examined the determinants of public goods provision. I control for existing

\footnotetext{
${ }^{8}$ Further, the motivation for spending in education is not always driven by redistributive concerns. Education is also a factor of production and aids economic development, as observed by trends in the emergence of welfare states in East Asia (Haggard and Kaufman 2008). In India too, some evidence suggests that public support for education in the last two decades was motivated by the goals of economic growth after the liberalization of the economy rather than pure redistribution (Chakrabarti and Mistree 2013).
} 
explanations and other factors that are likely to influence redistribution. Annex B provides a summary of the sources of data and estimation methods employed by existing studies as well as the controls I use to account for these theories.

Economic Factors: As discussed earlier, state capacity can be expected to have an independent effect on public support for development. I measure state capacity as a product of state's fiscal capacity and extractive capacity (Mann 1984; Soifer 2008). Fiscal capacity is conceptualized as the resources available with the state, as reflected by its total expenditure. In line with existing conceptions of state capacity based on taxation, I measure extractive capacity as the ratio of State's Own Taxes to its income or NDSP (Besley and Persson 2007). Two, economic development is likely to generate demands for social goods as well as the capacity to meet these needs (Lipset 1959; Przeworski and Limongi 1997). In the Indian context, Datt and Ravallion (1998; 2002) find that parts of the country with better infrastructure and human resources at the time of Independence were more successful in reducing poverty. I control for economic development through data on Net State Domestic Product (NDSP). Third, transfers from the federal government can also affect a state's spending decisions by influencing the size of its overall budget (Khemani 2003; Rodden and Wilkinson 2004). I control for central government assistance by accounting for different sources of federal funding - grants-in-aid, central plan schemes, and centrally sponsored schemes. Finally, I control for the potential impact of income inequality through data on intra-state rural and urban gini (Lupu and Pontusson 2011; Paul and Verdier 1996).

Social Factors: A large body of work emphasizes a strong negative correlation between ethnic diversity and public goods provision (Alesina and Ferrara 1999; Miguel and Gugerty 2005). In the Indian context, Banerjee and Somanathan (2007) find that greater religious and caste-based fragmentation weakens the provision of public services. Ethnic diversity may also affect development indirectly through the party system. Chhibber and Nooruddin (2004) argue that since two-party systems require political parties to build broad cross-cleavage coalitions by providing public services accessible to all groups, they are likely to more development oriented. Thachil and Teitelbaum (2015) find that "narrow ethnic parties" entrench patronage politics, while "encompassing ethnic parties" are associated with higher levels of developmental spending. The literature on social capital suggests that social cohesion should support collective action (Putnam, Leonardi, and Nanetti 1993; Krishna 2002). Most research on social 
capital in the Indian context is based micro-level qualitative studies (Krishna 2002). A notable exception is Singh (2016). She finds a positive relationship between cultural cohesion, measured through the level of subnationalism, and social development outcomes. I control for ELF, party systems, and subnationalism.9

Political Factors: A number of scholars have argued that social democratic parties and left-ideology are more likely to support wider social entitlements (Hall and Soskice 2003; E. Huber, Ragin, and Stephens 1993; Sandbrook et al. 2007; Esping-Andersen 1990). In the Indian context, the effect of social democratic parties on development has largely been explored qualitatively, most notably by Kohli (1987). I control for the effect of social democratic parties by coding for left-led coalitions through data from the Election Commission of India and other secondary sources. I also control for other party systems including government led by a center parties, right-wing parties, Congress, and BJP-led coalitions, and regional parties. Finally, following the seminal work on government responsiveness and political consciousness by Besley and Burges (2002), I control for turnout in state assembly elections.

Other Structural Factors: Since upper caste resistance to caste-based mobilization is a function of underlying social structure (Jaffrelot 2003; Varshney 2000), I control for the proportional population of upper caste. Secondly, we can expect state government policy to be influenced by the larger trends in politics and macro-economic policy. The variable, political period, accounts for three distinct phases: i) 1947 to 1967, when economic policy relied on a socialist central-planning model and the center and most states were dominated by the Congress Party (Kothari 1971), ii) 1967 to 1991 witnessed the emergence of wide range of national and regional parties but the economy continued to be controlled by central planning, and iii) the period from 1991 is marked by liberalization of the economy. I also control for different decades as a robustness check (Table D3). Finally, I account for pre-existing level of development by controlling for baseline levels of literacy. This also helps offset the potential limitations of using proportional spending as a dependent variable.

\section{Estimation Strategy}

\footnotetext{
9 The religion-ELF account for all major religions - Hindus, Muslims, Christians, Sikhs, Buddhists, Jains and others and the caste ELF includes data on Scheduled Castes (SC) and Scheduled Tribes (ST) in addition to religion.
} 
The variables described in the previous section include all major Indian states from 1960 to 2012 and account for about 95\% of India's population. Given that caste-based inequality (that is time invariant) is central to the theory and many controls are slow moving, I employ random effects estimators (2011; Wilson and Butler 2007; Clark and Linzer 2015; Beck 2001). The Hausman Test provides additional confidence that the variation across states in the data is random and uncorrelated with the independent variables (Table D1). Specifically, I run regression models of the form:

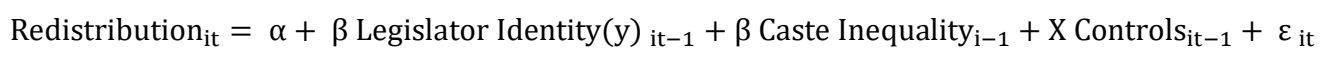

The main model employs random effects with lagged dependent variable (lagged by 1 year) and cluster standard errors at the state level to control for heteroscedasticity and autocorrelation. I run separate models for backward caste and lower caste representation to avoid possible collinearity. Table B9 summarizes the estimation strategy that other studies of comparative subnational development on India have employed.

\section{FINDINGS}

\section{Does the Identity of the Political Elite matter for Redistribution?}

Figure 4 plots the relationship between the caste identity of legislators in state governments and proportional spending in social sectors. As theories on class-coalitions and redistribution would predict, redistribution declines with increase in upper caste representation. The trend is positive for both backward and lower castes. Regression analysis aims to test the statistical significance of this association by accounting for a number of other explanations. 
Figure 4: Caste-based Representation and Redistribution in Indian States (1960-2009)
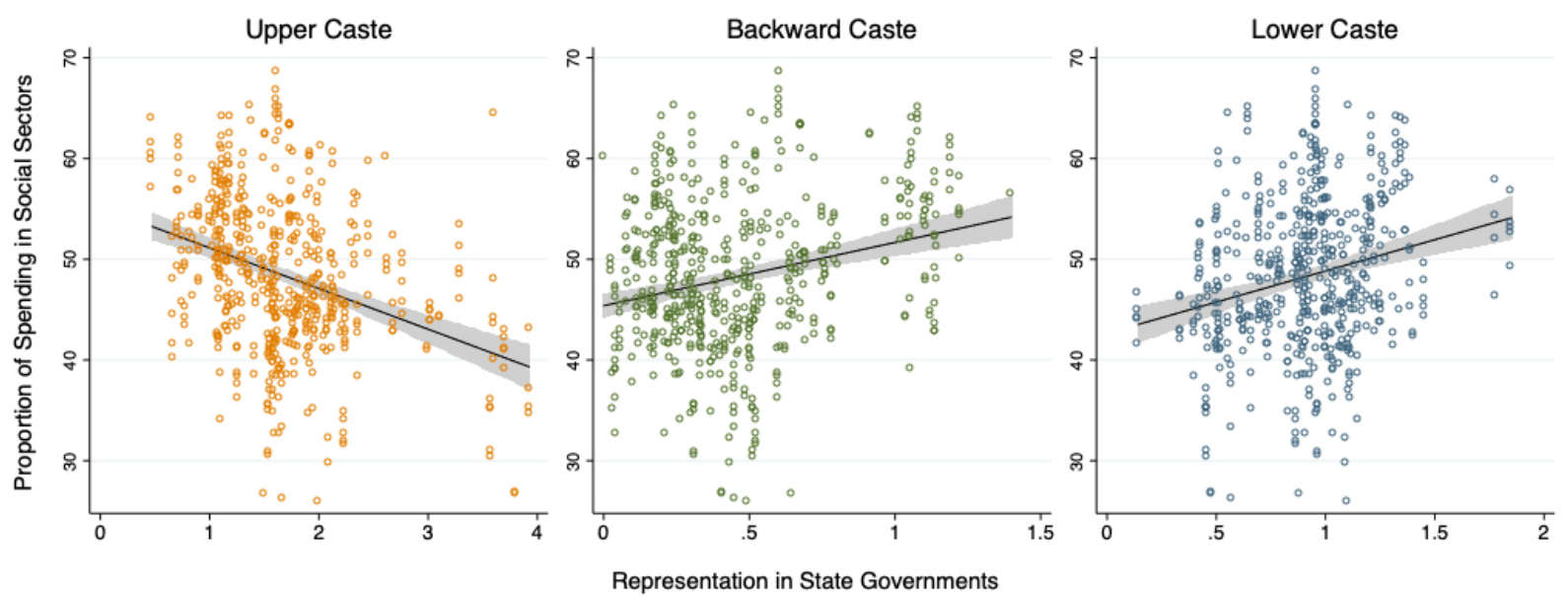

Table 1 presents the main models, controlling for the main set of alternative theories: state capacity, state domestic product, ethnic fractionalization, left-led government, voter turnout, subnational cohesion, proportion of upper caste population, political periods, and literacy rate as a proxy for preexisting levels of development. Models 1 and 2 examine the relationship between caste representation and redistribution in the state legislature. Models 3 and 4 examine representation in the government, that is directly responsible for policy decisions. Models 5 and 6 employ an alternative unit of analysis - relying on government-term, rather than state-year. Finally models 7 and 8 employ an alternative measure of caste inequality based on BGI. Models 3-8 examine representation in the government.

Consistent with expectation, upper caste representation has a negative and significant association with redistribution, at the 0.01 level, across all model specifications. Coefficients for caste-based inequality are also negative and highly significant. This is especially interesting since income inequality or Gini coefficient is not significant (Col 3, Table D3). Since caste inequality captures upper caste control over resources, high inequality is indicative of upper caste influence over state policy. Backward and lower caste representation are surprisingly not significant. Backward caste representation is generally positive. Lower caste representation presents negative coefficients in a number of models. 
Table 1: Caste Identity of Political Elite and Redistribution

\begin{tabular}{|c|c|c|c|c|c|c|c|c|}
\hline & (1) & $(2)$ & (3) & (4) & (5) & (6) & (7) & (8) \\
\hline $\begin{array}{l}\text { Upper Caste } \\
\text { Representation }\end{array}$ & $\begin{array}{c}-3.449 * * * \\
(0.641)\end{array}$ & $\begin{array}{c}-3.822 * * * \\
(0.663)\end{array}$ & $\begin{array}{c}-3.326 * * * \\
(0.560)\end{array}$ & $\begin{array}{c}-3.567 * * * \\
(0.546)\end{array}$ & $\begin{array}{c}-4.117^{* * *} \\
(0.840)\end{array}$ & $\begin{array}{c}-5.441 * * * \\
(0.969)\end{array}$ & $\begin{array}{c}-3.380 * * * \\
(0.810)\end{array}$ & $\begin{array}{c}-3.160 * * * \\
(0.691)\end{array}$ \\
\hline $\begin{array}{l}\text { Backward Caste } \\
\text { Representation }\end{array}$ & $\begin{array}{c}1.250 \\
(1.737)\end{array}$ & & $\begin{array}{c}1.334 \\
(1.456)\end{array}$ & & $\begin{array}{c}2.850 \\
(1.992)\end{array}$ & & $\begin{array}{c}0.902 \\
(1.786)\end{array}$ & \\
\hline $\begin{array}{l}\text { Lower Caste } \\
\text { Representation }\end{array}$ & & $\begin{array}{l}-1.040 \\
(1.550)\end{array}$ & & $\begin{array}{l}-0.283 \\
(1.356)\end{array}$ & & $\begin{array}{l}-4.668^{*} \\
(2.570)\end{array}$ & & $\begin{array}{c}1.528 \\
(1.028)\end{array}$ \\
\hline $\begin{array}{l}\text { Caste-based } \\
\text { Inequality }\end{array}$ & $\begin{array}{c}-1.860 * * * \\
(0.668)\end{array}$ & $\begin{array}{c}-1.894 * * * \\
(0.716)\end{array}$ & $\begin{array}{c}-1.728^{* * *} \\
(0.669)\end{array}$ & $\begin{array}{c}-1.712 * * \\
(0.705)\end{array}$ & $\begin{array}{c}-1.916 * * * \\
(0.717)\end{array}$ & $\begin{array}{c}-2.150 * * * \\
(0.634)\end{array}$ & $\begin{array}{c}-23.40 * * \\
(11.43)\end{array}$ & $\begin{array}{c}-23.93^{* *} \\
(10.25)\end{array}$ \\
\hline State Capacity & $\begin{array}{c}-7.889 * * * \\
(2.313)\end{array}$ & $\begin{array}{c}-7.703 * * * \\
(2.327)\end{array}$ & $\begin{array}{c}-7.914^{* * *} \\
(2.016)\end{array}$ & $\begin{array}{c}-7.757 * * * \\
(2.075)\end{array}$ & $\begin{array}{c}-9.961 * * * \\
(3.283)\end{array}$ & $\begin{array}{c}-9.217^{* * *} \\
(3.145)\end{array}$ & $\begin{array}{c}-7.120 * * * \\
(2.200)\end{array}$ & $\begin{array}{c}-6.755 * * * \\
(2.238)\end{array}$ \\
\hline Log NDSP & $\begin{array}{c}-7.425^{* * *} \\
(2.878)\end{array}$ & $\begin{array}{c}-8.158 * * * \\
(2.267)\end{array}$ & $\begin{array}{c}-7.023^{* * *} \\
(2.578)\end{array}$ & $\begin{array}{c}-7.762 * * * \\
(2.041)\end{array}$ & $\begin{array}{c}-4.938 * * \\
(2.484)\end{array}$ & $\begin{array}{c}-6.691 * * * \\
(2.172)\end{array}$ & $\begin{array}{l}-5.098^{*} \\
(2.621)\end{array}$ & $\begin{array}{c}-5.601 * * * \\
(1.906)\end{array}$ \\
\hline ELF (Caste) & $\begin{array}{c}16.58 * * \\
(8.446)\end{array}$ & $\begin{array}{c}15.34 * * \\
(7.683)\end{array}$ & $\begin{array}{c}18.51^{* *} \\
(7.205)\end{array}$ & $\begin{array}{c}16.53 * * \\
(7.385)\end{array}$ & $\begin{array}{c}17.46^{* *} \\
(8.459)\end{array}$ & $\begin{array}{c}16.19 * * \\
(7.240)\end{array}$ & $\begin{array}{c}25.06 * * \\
(10.53)\end{array}$ & $\begin{array}{c}21.52 * * \\
(9.428)\end{array}$ \\
\hline $\begin{array}{l}\text { Left-led } \\
\text { Government }\end{array}$ & $\begin{array}{l}2.172^{*} \\
(1.172)\end{array}$ & $\begin{array}{l}2.104^{*} \\
(1.171)\end{array}$ & $\begin{array}{c}1.548 \\
(1.558)\end{array}$ & $\begin{array}{c}1.501 \\
(1.463)\end{array}$ & $\begin{array}{c}2.324^{* *} \\
(1.145)\end{array}$ & $\begin{array}{l}2.466^{*} \\
(1.379)\end{array}$ & $\begin{array}{c}0.342 \\
(1.493)\end{array}$ & $\begin{array}{c}0.303 \\
(1.307)\end{array}$ \\
\hline Turnout & $\begin{array}{c}0.109 * \\
(0.0604)\end{array}$ & $\begin{array}{c}0.109 * \\
(0.0619)\end{array}$ & $\begin{array}{c}0.109 * \\
(0.0594)\end{array}$ & $\begin{array}{c}0.111^{*} \\
(0.0617)\end{array}$ & $\begin{array}{l}0.173 * * \\
(0.0745)\end{array}$ & $\begin{array}{l}0.161^{* *} \\
(0.0732)\end{array}$ & $\begin{array}{c}0.0823 \\
(0.0588)\end{array}$ & $\begin{array}{c}0.0909 \\
(0.0605)\end{array}$ \\
\hline Sub-nationalism & $\begin{array}{c}0.488 \\
(0.697)\end{array}$ & $\begin{array}{c}0.458 \\
(0.689)\end{array}$ & $\begin{array}{c}0.567 \\
(0.680)\end{array}$ & $\begin{array}{c}0.527 \\
(0.661)\end{array}$ & $\begin{array}{c}0.306 \\
(0.691)\end{array}$ & $\begin{array}{c}0.289 \\
(0.639)\end{array}$ & $\begin{array}{c}1.197 * * \\
(0.530)\end{array}$ & $\begin{array}{l}1.114^{* *} \\
(0.553)\end{array}$ \\
\hline $\begin{array}{l}\text { Upper Caste } \\
\text { Population (\%) }\end{array}$ & $\begin{array}{c}-0.0937 * * * \\
(0.0229)\end{array}$ & $\begin{array}{c}-0.100 * * * \\
(0.0222)\end{array}$ & $\begin{array}{c}-0.0861 * * * \\
(0.0201)\end{array}$ & $\begin{array}{c}-0.0932 * * * \\
(0.0217)\end{array}$ & $\begin{array}{c}-0.123 * * * \\
(0.0285)\end{array}$ & $\begin{array}{c}-0.144 * * * \\
(0.0257)\end{array}$ & $\begin{array}{c}-0.0652 * * \\
(0.0261)\end{array}$ & $\begin{array}{c}-0.0645^{* * *} \\
(0.0220)\end{array}$ \\
\hline $\begin{array}{l}\text { 1968-1991 } \\
\text { (base 1960-67) }\end{array}$ & $\begin{array}{c}5.352 * * * \\
(1.693)\end{array}$ & $\begin{array}{c}5.326 * * * \\
(1.715)\end{array}$ & $\begin{array}{c}5.225^{* * *} \\
(1.717)\end{array}$ & $\begin{array}{c}5.138 * * * \\
(1.776)\end{array}$ & $\begin{array}{c}5.383^{* * *} \\
(1.878)\end{array}$ & $\begin{array}{c}5.506^{* * *} \\
(2.015)\end{array}$ & $\begin{array}{c}5.350 * * * \\
(1.645)\end{array}$ & $\begin{array}{c}5.183^{* * *} \\
(1.649)\end{array}$ \\
\hline $\begin{array}{l}\text { 1992-2012 } \\
\text { (base 1960-67) }\end{array}$ & $\begin{array}{c}8.543^{* * *} \\
(2.568)\end{array}$ & $\begin{array}{c}8.736 * * * \\
(2.628)\end{array}$ & $\begin{array}{c}7.952 * * * \\
(2.312)\end{array}$ & $\begin{array}{c}8.044^{* * *} \\
(2.343)\end{array}$ & $\begin{array}{c}7.159 * * \\
(3.150)\end{array}$ & $\begin{array}{c}8.097 * * \\
(3.337)\end{array}$ & $\begin{array}{c}7.557^{* * *} \\
(2.161)\end{array}$ & $\begin{array}{c}7.467^{* * *} \\
(2.149)\end{array}$ \\
\hline Literacy Rate & $\begin{array}{c}0.178^{* * *} \\
(0.0579)\end{array}$ & $\begin{array}{c}0.193 * * * \\
(0.0498)\end{array}$ & $\begin{array}{c}0.172 * * * \\
(0.0598)\end{array}$ & $\begin{array}{c}0.192 * * * \\
(0.0540)\end{array}$ & $\begin{array}{c}0.147^{* * *} \\
(0.0400)\end{array}$ & $\begin{array}{c}0.167^{* * *} \\
(0.0468)\end{array}$ & $\begin{array}{l}0.127^{* *} \\
(0.0590)\end{array}$ & $\begin{array}{c}0.148 * * * \\
(0.0534)\end{array}$ \\
\hline Constant & $\begin{array}{c}104.2^{* * *} \\
(30.01)\end{array}$ & $\begin{array}{c}113.6^{* * *} \\
(23.51)\end{array}$ & $\begin{array}{c}99.10 * * * \\
(26.69)\end{array}$ & $\begin{array}{c}107.7 * * * \\
(20.66)\end{array}$ & $\begin{array}{c}80.27^{* * *} \\
(26.29)\end{array}$ & $\begin{array}{c}105.9 * * * \\
(22.95)\end{array}$ & $\begin{array}{c}78.77^{* * *} \\
(27.41)\end{array}$ & $\begin{array}{c}82.88^{* * *} \\
(18.78)\end{array}$ \\
\hline
\end{tabular}

\begin{tabular}{|c|c|c|c|c|c|c|c|c|}
\hline$N$ & 537 & 537 & 537 & 537 & 139 & 139 & 537 & 537 \\
\hline
\end{tabular}

These findings further survive the inclusion of a number of additional controls and other estimation techniques presented in Annex D. Table D2 includes estimation with OLS with PCSE (Col 1 \& 2), random 
effects without lagged DV (Col 3 \& 4), use of proportional spending in health and education as a DV (Col 5 \& 6). The first 6 models examine representation in government. Col 7 \& 8 examine representation of legislators who hold important party office. Though the quality of this data on party office is not consistent across all states, the coefficients for upper caste representation remain negative and significant. Tables D3 and D4 account for the remaining set of controls discussed in the previous section. Table D3 accounts for religion: ELF based on religion (Col 1), Muslim representation (Col 2). It also includes controls for other economic and structural factors: income inequality (Col 3), central government transfers (Col 4), economic growth (Col 5), and controls for decades instead of political periods (Col 6). Finally, Table D4 includes a host of other political variables: encompassing and narrow ethnic parties (Col 1), coalition government (Col 2), and party-types: centrist-led (Col 3), rightled (Col 4), Congress-led (Col 5), BJP-led (Col 6), and regional party-led (Col 7).

\section{If not Redistribution, what do Marginal Groups want?}

How should we make sense of these results? There is a wide consensus among scholars of Indian politics that the nature of redistributive politics in India has been strongly shaped by the caste inequality rather than pure material deprivation, what has been referred as the "politics of dignity" (Weiner 2001; Varshney 2000; Ahuja 2019; Jaffrelot 2003; Witsoe 2013; Jensenius 2017). As opposed to the conventional left-right paradigm, ideological differences in Indian politics is based on the role of the state in regulating social norms and accommodating marginalized groups (P. K. Chhibber and Verma 2018). Influential thinkers on caste like Ambedkar, Lohia and Periyar, that most contemporary lower caste parties draw from, have advocated for group-based state intervention since they believed that caste, more than class, is the basis of Indian society (Yadav 2010). Caste-based movements have generally been led by upwardly mobile members of lower caste groups who faced humiliation in spite of having broken the class barrier. In instances when lower caste parties assumed political power, policies related to symbolic and descriptive representation became central to the agenda of many of these governments. Lalu Prasad Yadav, for example, famously declared his agenda as "vikas nahi, samman chahiye" (we need dignity, not development) when his party formed the first lower caste government in Bihar in 1990. He is not an exception. 
The Channar Revolt from 1813 to 1859 in Kerala, considered one of the first instances of lower caste mobilization in India, was led by upwardly mobile Nadars (a Shudra sub-caste) who fought for Nadar women's right to wear upper-body clothes to cover their breasts, like upper caste women (Mathew 1982). Kerala is celebrated as an exceptional case of successful class mobilization and social democracy in the developing world (Heller 2000; Sandbrook et al. 2007; M. Desai 2002), but political mobilization in the state focused on group-based interventions and representational demands as late as the 1960s (G. Mathew 1982; Jeffrey 1976; Ouwerkerk 1994). In the adjoining state of Tamil Nadu, political mobilization by the Justice Party was led by wealthy landowning lower castes who experienced a sense of "status dislocation" due to colonial policies that privileged Brahmins (Subramanian 2000). In interviews with Justice Party leaders, Barnett (1976) found that their decision to join the movement was almost always triggered by personal experiences of insult at the hands of Brahmins. The party's manifesto, aptly named the "Non-Brahmin Manifesto," advocated for greater representation of Shudras in administration and education. The Justice Party lobbied the colonial government to implement reservation policies when it won the Madras Presidency Elections in 1920, a policy that subsequent governments continued to promote. Tamil Nadu currently has the highest caste-based reservation at 69\% (Radhakrishnan 1990; Subramanian 2000).

About thirty state-level OBC commissions and committees have been established since Independence (see Annex C). In most northern states, however, reservations could be implemented only after OBC governments came to power in the nineties (Figure 5). The South had the advantage of a longer history of lower caste movements and a colonial administration that used group-based policies and quotas as an strategy to strengthen their control of India (Galanter 1984; Jensenius 2017). Reservation policies were more difficult to enact after Independence since modernist upper caste governments at the center believed that socialist policy could erase caste inequality (Jaffrelot 2003). In 1963, the Supreme Court passed a judgement in the famous Balaji vs. State of Mysore case that restricted overall caste quotas $50 \%$ on grounds of individual merit. A number of states in the South challenged this ruling and restored $\mathrm{OBC}$ reservations, generally through negotiations with the central government. 
Figure 5: OBC and SC \& ST Reservations in Public Employment in Indian States by decade

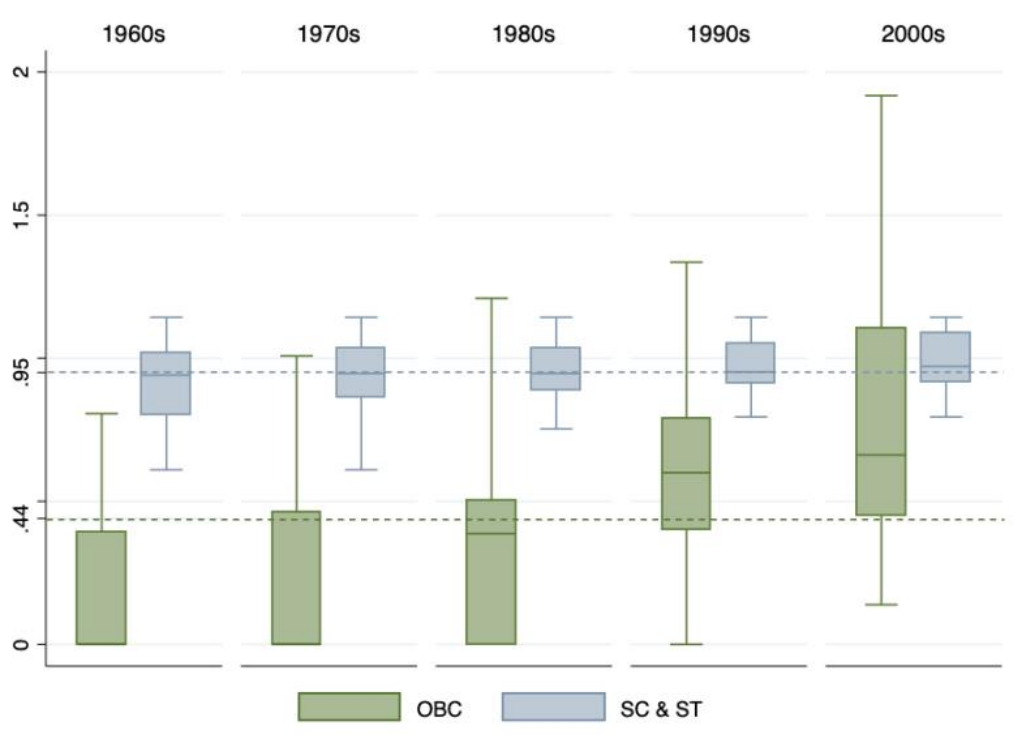

The limitation on legislation in the North, to an extent, was bypassed through informal appointments of lower caste officers in the administration. The lower bureaucracy and the police - elements of the state that directly interact with the public, were targeted in particular (Weiner 2001; Jaffrelot 2003; Witsoe 2013; Chakrabarti 2019). The number of upper caste Additional District Magistrates in Uttar Pradesh under the OBC Chief Minister Mulayam Singh Yadav, for example, were reduced from 43 (out of 63) to only 13 in the first six months of his tenure (Jaffrelot 2003). In Bihar, the proportion of lower caste heads of police stations more than doubled under the Chief Ministership of Lalu Yadav (Chakrabarti 2019). Issues related to affirmative action became key to the policy agenda of lower caste governments. Chandra (2000), for example, notes that almost 92\% of the campaign speeches of the BSP, India's first major political party led by Dalits, concerned caste-based social justice. Similarly, issues related to lower castes doubled in assembly speeches in Bihar when Yadav assumed power (Chakrabarti 2019). Lower caste governments also promoted symbolic representation. Even as the state struggled to provide the most basic public services, the government of Uttar Pradesh under the BSP Chief Minister Mayawati dedicated large sums of resources on Dalit iconography. More than $\$ 400$ million, for example, was spent on five memorials in the capital city of Lucknow between 2007 and 2009 alone (India Today 2011). 


\section{When do Marginal Groups demand Redistribution?}

Does identity politics negate development, as many scholars have suggested (Kohli 2012; Mehta 2003; Witsoe 2013; A. V. Banerjee and Pande 2007)? As discussed earlier, backward castes and lower castes generally represent two different kinds of politics - SC representation is mandated by the state, while backward caste representation reflects mobilization by OBC parties as they broke away from upper caste clientelistic networks. Should the nature of mobilization matter for redistributive politics? Can caste-based reservations support social policy? To answer these questions, I examine employ two strategies.

Figure 6: Predicted Redistribution based on Backward Caste Representation

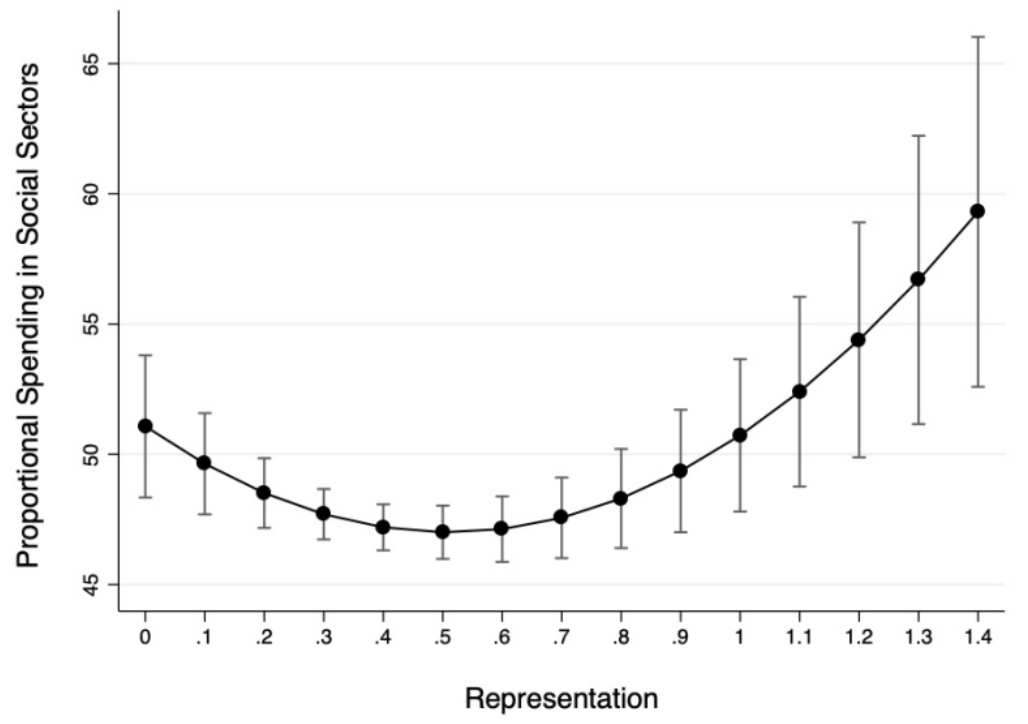

Note: Bars indicate 95\% confidence intervals. Controls: upper caste representation, state capacity, state domestic product, ethnic fractionalization, left-led government, voter turnout, subnational cohesion, proportion of upper caste population, proportion of backward caste population, political periods, literacy rate.

One, I examine the non-linear patterns in the relationship between representation and redistribution. This is based on the premise that at lower levels of representation, marginal groups are more likely to be coopted by upper castes and would hence reflect the elite policy preferences. Table D5 introduces squared representation to the original set of explanatory variables. Lower caste representation continues to remain insignificant ( $\mathrm{Col} 1$ ), but backward caste representation presents a significant, $\mathrm{U}$ shaped, association with redistribution (Cols $2 \& 3$ ). We might expect this pattern to be driven by 
structural factors - backward castes comprise close to half the population. But the coefficients remain significant at the 0.01 level even after controlling for proportion of backward caste population (Col 3). Figure 6 presents the predicted proportion of social spending across the range of backward caste representation. These results are further not driven by outliers, which could be a concern given the transformation. Cols 4 and 5 presents results based on a restricted sample by excluding observations of backward caste representation greater than $95^{\text {th }}$ and $90^{\text {th }}$ percentiles at either ends of the distribution. The restricted sample in fact generates larger coefficients. The findings further hold when we examine in representation in the state legislature and party office (Cols 6 and 7 respectively) and use of proportional spending in health and education as a DV (Col 8). Existing data does not allow us to test the specific mechanisms that drives this non-linear pattern. The first wave of backward castes may be wealthier landowners whose interests are closer to elites or it may reflect the nature of alliances with upper castes until OBC parties are independently strong.

Figure 7: Average Marginal Effects of OBC Reservation on Redistribution
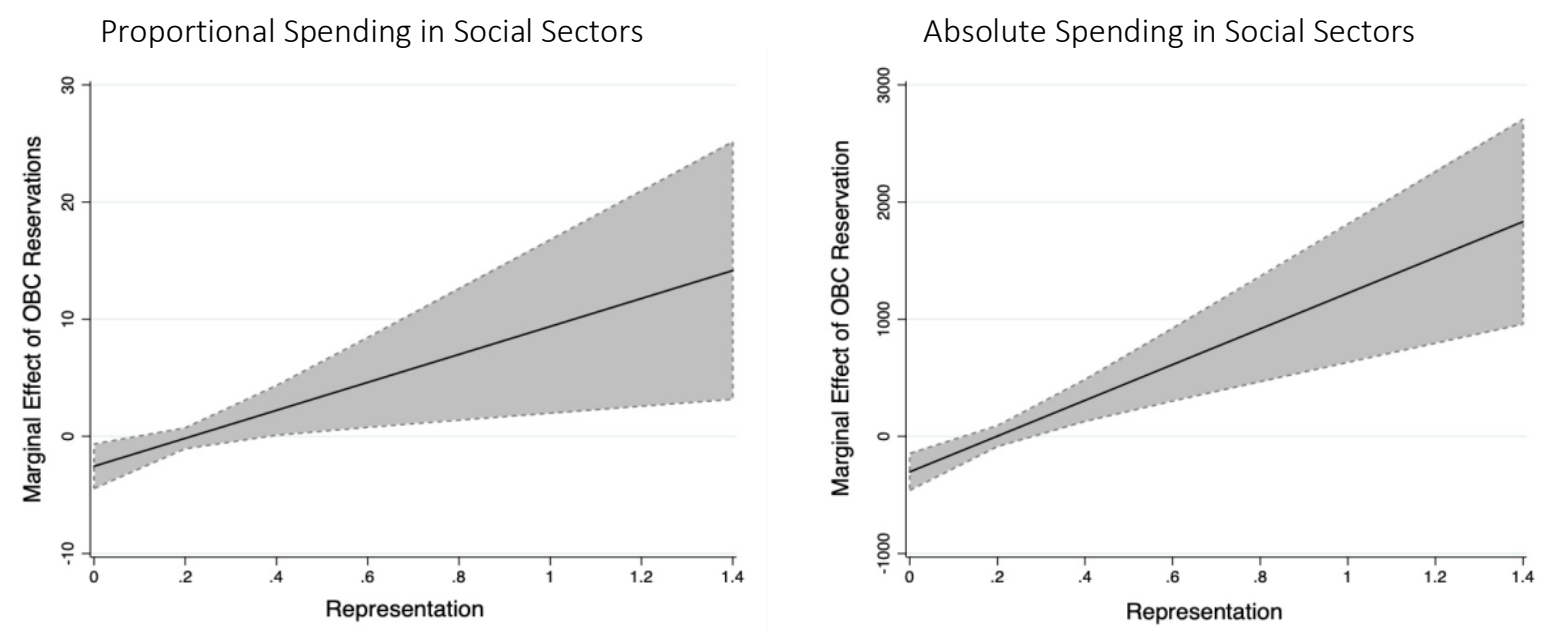

Note: Shaded area indicates 95\% confidence intervals. Controls: upper caste representation, state capacity, state domestic product, ethnic fractionalization, left-led government, voter turnout, subnational cohesion, proportion of upper caste population, proportion of backward caste population, literacy rate.

Next, I examine if the impact of representation is mediated by caste-based reservations. I do so by examining the interaction effects of caste-based reservation and lower and backward caste representation respectively. Data on state-level SC, ST and OBC reservations from 1950 onwards is compiled from a number of government reports, secondary sources, and newspaper reports (see 
Annex C and Figure 5). Consistent with (Khanna 2020) who examined the effects of OBC reservation on education, I use OBC population estimates from the $55^{\text {th }}$ Round of National Sample Survey (NSS). Echoing the previous set of results, the interaction of lower caste representation in government and lower caste administrative reservations is not significant (Table D6). These findings remain consistent after accounting for lagged effects of reservations (Cols 1-3). In contrast, the interaction of backward caste representation and $\mathrm{OBC}$ reservation is positive and significant (Cols 4-7). Its effects increase the longer that reservations have been in place (lagged by 3, 5, 7 and 10 years respectively). Figure 7 plots the marginal effects of $\mathrm{OBC}$ reservation on redistribution, as measured by both proportional and absolute spending in social sectors (Col 4 Table D6 and Col 1 Table D7 respectively). Table D7 presents additional robustness checks. The results remain consistent after using lagged DV (Col 1-3) as well as when we measure reservations with an alternate estimate for OBC population (Col 4-6), again accounting for lagged effects of reservations in both scenarios.

\section{DISCUSSION}

The policy preference of upper caste representatives corresponds to our understanding of the economic elite (Acemoglu and Robinson 2006; Boix 2003; Esping-Andersen 1990; Rueschemeyer, Huber, and Stephens 1992). Research on India also finds that business-friendly policies have been most successful in states that are led by wealthy upper caste groups (Murali 2017). More than just alignment of interests, bias against lower castes can hinder redistribution. Myron Weiner (1991) in his classic study of child labor in India uncovered a widespread belief amongst upper caste policy makers that the education system should reinforce the occupational divisions of the caste system, between people who work their minds and people who work with their hands.

The findings on lower castes, though surprising from the perspective of working-class coalitions, are consistent with the literature on India. Though Dalit representation had led to significant gains in reducing caste-based discrimination (Chauchard 2014; Girard 2018), its distributional effects have been limited (Jensenius 2017; Dunning and Nilekani 2013). Mainstream parties are known to choose weak SC leaders. SCs further have limited opportunities of advancement in the party organization (Jensenius 2017; Chandra 2004; Jaffrelot 2003). A survey conducted in the early sixties found that SC 
legislators rarely spoke in the Parliament, even on policies pertaining to Dalit rights (Jaffrelot 2003). Kanshi Ram, one of the most prominent SC politicians, famously referred to SC politicians elected through the quotas as chamchas (sycophants) who merely follow the orders of the party leaders (Jensenius 2017). Affirmative action has ensured Dalit representation in legislatures, but in the absence of strong Dalit mobilization their policy preferences are likely to be diluted by the agenda of the parties that they are part represent (Ahuja 2019; Jensenius 2017).

While empirical research on backward caste representation and development is limited, scholars have been skeptical about the redistributive potential of OBC politics (Kohli 2012; Jaffrelot 2003; Mehta 2003; Murali 2017; Witsoe 2013). Governments led by backward caste parties in states like Bihar and Uttar Pradesh have been described as neo-patrimonial - states that pursue entrenched personal interests at the expense of public goods (Kohli 2012). Their abrasive treatment of upper caste bureaucrats has been interpreted as the "politics of retribution" (Mehta 2003) and OBC reservations have been explained as "an offer to share the spoils of office, not a promise of social justice for the poor" (Weiner 2001, 204). While concerns of patronage and mis-governance in some states are not without merit, this research suggests that once backward castes representation crosses a certain threshold, we do observe an increase in prioritization of social spending. Further, combined with OBC representation in the bureaucracy, backward caste support for redistribution rises. It is important to note that $\mathrm{OBC}$ mobilization is relatively new in North India and overall, backward castes are still underrepresented in most state governments. If the political trajectory of the southern states provides some cues to the future of OBC politics, concerns for group-based and representational demands gradually gave way to a broad welfare agenda, encompassing parties, and an inclusive civil society (Varshney 2000; Heller 2000; Thachil and Teitelbaum 2015; Ahuja 2019).

Though this research doesn't test the mechanisms through which changes in the caste composition of the bureaucracy can influence the policy decisions of the political elite, existing studies suggest that representation can transform the structural conditions that generate demand for redistribution. Representation can improve the design and implementation of social programs by reducing discrimination (Quadagno 1994; Dee 2005; Weiner 1991), generating additional incentives for civil servants through social sanctions by members of their groups (Tsai 2007), and enabling access to better information on marginal groups (Bardhan 2002). Upper caste government employees, for 
example, have been shown to discriminate against Dalits in local healthcare and nutrition programs (Mosse 2018). Relatedly, representation in the local bureaucracy can expand the membership of the public sphere and create the space for marginal groups to make claims on the state, eventually generating demand for social goods (Rao and Sanyal 2010; Kruks-Wisner 2018). It can also contribute towards breaking down elite patronage networks at the local level, thus reducing barriers in assigning state resources to its intended beneficiaries (Witsoe 2013). Finally, representation can improve policy implementation by reducing the conflict between legislative and executive parts of the government. Status difference between the political representatives and bureaucrats, for example, has been shown to weaken state capacity and public goods provision in India (Witsoe 2013; S. Mathew and Moore 2011; Suryanarayan 2017).

\section{THEORETICAL IMPLICATIONS}

This research contributes towards our understanding of welfare state and public goods provision in multiethnic societies. Recent scholarship on diversity and development finds that inequality between groups is a stronger predictor of public goods provision than ethnic diversity or group-based cultural differences per se (Baldwin and Huber 2010; Kustov and Pardelli 2018). In hierarchical societies, however, economic disparity between groups is generally a reflection of historical discrimination. In such contexts, the social distance between groups can not only hinder cross-class alliances that are necessary for successful class-based mobilization as scholars of welfare politics have suggested (Rueschemeyer, Huber, and Stephens 1992; Quadagno 1994; Katznelson 2005; Lupu and Pontusson 2011), but this research highlights the complex ways through which status shapes the nature of redistributive politics.

Status inequality is not just a stronger predictor of redistribution than income inequality, it also affects the behavior of voters and political elites (Suryanarayan 2018; Mutz 2018; Chandra 2004; Malik 2019). Status further broadens the policy agenda in hierarchical societies. In contrast to class-based politics, marginal groups fight for redistribution as well as representation. Concern for status may even trump class interests - poor voters from dominant groups may vote against their material interests (Suryanarayan 2018; Mutz 2018) and representation may be prioritized over redistribution. Findings from India however suggest that representation of marginal groups in the bureaucracy can generate 
support for redistribution from political representatives from marginal groups. The mechanisms that connect the status of the political and executive parts of the government to development outcomes open up an exciting research agenda on ethnicity and state capacity (Wimmer 2015; Singh and vom Hau 2016; Suryanarayan and White 2019; Suryanarayan 2017).

From the perspective of Indian politics, this research takes a broad view of redistributive politics spanning more than five decades and all major states. Existing research on descriptive representation in India have generally explored narrowly defined outcomes, focusing almost exclusively on SCS (Jensenius 2017; Dunning and Nilekani 2013; Pande 2003; Chauchard 2014). To the best of my knowledge, this study employs the largest panel on legislator identity and caste-based reservations in public employment at the state level. The outcome variable, based on the entire range of social spending, is also more comprehensive than existing studies. The breadth of the data allows me to examine the complex relationship between types of caste groups, status inequality, and redistribution. Findings from this study push back against influential works that have been pessimistic about the redistributive potential of OBC politics (Kohli 2012; Jaffrelot 2003; Mehta 2003; Murali 2017; Witsoe 2013). Towards this end, this study emphasizes the need for further research on the impact of backward castes on development. From a policy perspective, the findings contribute towards an emerging research agenda on the effects of caste-based affirmative action (Jensenius 2017; Gulzar, Haas, and Pasquale 2020; Khanna 2020; Bhavnani and Lee 2019).

Though the concept of status is relatively unexplored in political science, the findings of this research present several parallels with the broad tenets of the literature on ethnicity and nationalism (Wimmer, Cederman, and Min 2009; Wimmer 2002; Horowitz 1970). According to this school, the transformation of societies from hierarchical empires to modern nations involves the incorporation of ethnic groups into the state-building process. The principles of modernity - "political participation, equal treatment before the law and protection from the arbitrariness of state power, dignity for the weak and poor, and social justice and security", Wimmer (2002) argues, "were fully realized only for those who came to be regarded as true members of the nation." Exclusion of certain groups from state power is at the heart of ethnic conflict (Wimmer, Cederman, and Min 2009). Much like lower caste elites in India, the emergence of a middle class in excluded groups is accompanied with the political struggle over access to state power, resulting in the ethnicization of the bureaucracy (Horowitz 1970; Wimmer 2002). The 
common thread that connects the egalitarian principles of the nation to the welfare state appears to be representation. Findings of this study strongly suggests that the path to redistribution in hierarchy societies has to address the questions of dignity along its way. 


\section{REFERENCES}

Acemoglu, Daron, and James A Robinson. 2006. Economic Origins of Dictatorship and Democracy. Cambridge; New York: Cambridge University Press.

Acharya, Avidit, Matthew Blackwell, and Maya Sen. 2016. "The Political Legacy of American Slavery." The Journal of Politics 78 (3): 621-41.

Ahuja, Amit. 2019. Mobilizing the Marginalized: Ethnic Parties Without Ethnic Movements. Oxford University Press.

Alesina, Alberto, and Eliana La Ferrara. 1999. "Participation in Heterogeneous Communities." NBER Working Paper No. 7155.

Baker, Christopher. 1976. "The Congress at the 1937 Elections in Madras." Modern Asian Studies 10 (4): 557-89..

Baldwin, Kate, and John Huber. 2010. "Economic versus Cultural Differences: Forms of Ethnic Diversity and Public Goods Provision." The American Political Science Review 104 (4): 644-62.

Banerjee, Abhijit, and Lakshmi lyer. 2005. "History, Institutions, and Economic Performance: The Legacy of Colonial Land Tenure Systems in India." The American Economic Review 95 (4): 1190-1213.

Banerjee, Abhijit, and Rohini Somanathan. 2007. "The Political Economy of Public Goods: Some Evidence from India." Journal of Development Economics 82 (2): 287-314.

Banerjee, Abhijit V., and Rohini Pande. 2007. "Parochial Politics: Ethnic Preferences and Politician Corruption." SSRN Scholarly Paper ID 1136706. Rochester, NY: Social Science Research Network.

Bardhan, Pranab. 2002. "Decentralization of Governance and Development." Journal of Economic Perspectives 16 (4): 185-205.

Barnett, Marguerite Ross. 1976. The Politics of Cultural Nationalism in South India. Princeton: Princeton University Press.

Beck, Nathaniel. 2001. "Time-Series-Cross-Section Data: What Have We Learned in the Past Few Years?" Annual Review of Political Science 4 (1): 271-293.

Beck, Nathaniel, and Jonathan N. Katz. 2011. "Modeling Dynamics in Time-Series-Cross-Section Political Economy Data." Annual Review of Political Science 14 (1): 331-52.

Berwick, Elissa, and Fotini Christia. 2018. "State Capacity Redux: Integrating Classical and Experimental Contributions to an Enduring Debate." Annual Review of Political Science 21 (1).

Besley, Timothy, and Robin Burgess. 2002. "The Political Economy of Government Responsiveness: Theory and Evidence from India." The Quarterly Journal of Economics 117 (4): 1415-51.

Besley, Timothy, and Torsten Persson. 2007. "The Origins of State Capacity: Property Rights, Taxation, and Politics." National Bureau of Economic Research.

Bhavnani, Rikhil R., and Alexander Lee. 2019. "Does Affirmative Action Worsen Bureaucratic Performance? Evidence from the Indian Administrative Service." American Journal of Political Science 00 (0): 116.

Bloom, Paul. 2010. "How Do Morals Change?" Nature 464 (7288): 490.

Boix, Carles. 2003. Democracy and Redistribution. Cambridge, UK; New York: Cambridge University Press.

Centeno, Miguel A., Atul Kohli, Deborah J. Yashar, and Dinsha Mistree, eds. 2017. States in the Developing World. Cambridge ; New York, NY: Cambridge University Press.

Chakrabarti, Poulomi. 2019. "One Nation, Many Worlds: Varieties of Developmental Regimes in India." PhD Dissertation, Providence RI: Brown University.

- - . 2020. "Measuring Caste-Based Inequality in Indian States."

Chakrabarti, Poulomi, and Dinsha Mistree. 2013. "Disaggregating Social Development: The Variant Politics of Education and Healthcare in India." Unpublished Paper. Brown University, Providence RI. 
Chandra, Kanchan. 2000. "The Transformation of Ethnic Politics in India: The Decline of Congress and the Rise of the Bahujan Samaj Party in Hoshiarpur." The Journal of Asian Studies 59 (01): 26-61. doi:10.2307/2658583.

- - . 2004. Why Ethnic Parties Succeed: Patronage and Ethnic Head Counts in India. Cambridge, UK; New York: Cambridge University Press.

Chauchard, Simon. 2014. "Can Descriptive Representation Change Beliefs about a Stigmatized Group? Evidence from Rural India." American Political Science Review 108 (02): 403-22.

Chhibber, Pradeep K., and Rahul Verma. 2018. Ideology and Identity: The Changing Party Systems of India. New York, NY, United States of America: Oxford University Press.

Chhibber, Pradeep, and Irfan Nooruddin. 2004. "Do Party Systems Count?: The Number of Parties and Government Performance in the Indian States." Comparative Political Studies 37 (2): 152-87.

Clark, Tom S., and Drew A. Linzer. 2015. "Should I Use Fixed or Random Effects?" Political Science Research and Methods 3 (02): 399-408.

Cramer, Katherine J. 2016. The Politics of Resentment: Rural Consciousness in Wisconsin and the Rise of Scott Walker. University of Chicago Press.

Dasgupta, Aditya. 2018. "Technological Change and Political Turnover: The Democratizing Effects of the Green Revolution in India." American Political Science Review 112 (4): 918-38.

Datt, Gaurav, and Martin Ravallion. 1998. "Why Have Some Indian States Done Better than Others at Reducing Rural Poverty?" Economica 65 (257): 17-38.

Dee, Thomas S. 2005. "A Teacher Like Me: Does Race, Ethnicity, or Gender Matter?" American Economic Review 95 (2): 158-65.

Desai, Manali. 2002. "The Relative Autonomy of Party Practices: A Counterfactual Analysis of Left Party Ascendancy in Kerala, India, 1934-1940." American Journal of Sociology 108 (3): 616-57.

Desai, Sonalde, and Amaresh Dubey. 2011. "Caste in 21st Century India: Competing Narratives," no. 11: 10.

Dunning, Thad, and Janhavi Nilekani. 2013. "Ethnic Quotas and Political Mobilization: Caste, Parties, and Distribution in Indian Village Councils." American Political Science Review 107 (01): 35-56.

Esping-Andersen, Gosta. 1990. The Three Worlds of Welfare Capitalism. Polity Press.

Fraser, Nancy. 1995. "From Redistribution to Recognition? Dilemmas of Justice in a 'post-Socialist' Age." New Left Review, 68-93.

Galanter, Marc. 1984. Competing Equalities: Law and the Backward Classes in India. First Printing edition. Berkeley: Univ of California Press.

Gandhi, Mohandas. 1983. Autobiography: The Story of My Experiments with Truth. New York: Dover Publications.

Girard, Victoire. 2018. "Don't Touch My Road. Evidence from India on Affirmative Action and Everyday Discrimination." World Development 103 (March): 1-13.

Gourevitch, Alex. 2015. "Police Work: The Centrality of Labor Repression in American Political History." Perspectives on Politics 13 (3): 762-73.

Gulzar, Saad, Nicholas Haas, and Benjamin Pasquale. 2020. "Does Political Affirmative Action Work, and for Whom? Theory and Evidence on India's Scheduled Areas." American Political Science Review, August, 1-17.

Haggard, Stephan, and Robert R. Kaufman. 2008. Development, Democracy, and Welfare States: Latin America, East Asia, and Eastern Europe. Princeton University Press.

Hajnal, Zoltan L. 2001. "White Residents, Black Incumbents, and a Declining Racial Divide." American Political Science Review 95 (3). Cambridge University Press: 603-17.

Hall, Peter A., and David Soskice. 2003. "Varieties of Capitalism and Institutional Change: A Response to Three Critics." Comparative European Politics 1 (2): 241-50.

Heller, Patrick. 2000. "Degrees of Democracy: Some Comparative Lessons from India." World Politics 52 (4): 484-519. 
Hoff, Karla, and Priyanka Pandey. 2006. "Discrimination, Social Identity, and Durable Inequalities." The American Economic Review 96 (2): 206-11.

Horowitz, Donald. 1970. Ethnic Groups in Conflict. University of California Press.

Houle, Christian, Paul D. Kenny, and Chunho Park. 2019. "The Structure of Ethnic Inequality and Ethnic Voting." The Journal of Politics 81 (1). The University of Chicago Press: 187-200.

Huber, Evelyne, Charles Ragin, and John D Stephens. 1993. "Social Democracy, Christian Democracy, Constitutional Structure, and the Welfare State." American Journal of Sociology 99 (3): 711-749.

Huber, John D., and Pavithra Suryanarayan. 2016. "Ethnic Inequality and the Ethnification of Political Parties: Evidence from India." World Politics 68 (1): 149-88.

India Today. 2011. "Mayawati Government Spends on Parks, Ignores Healthcare, Education and Infrastructure," August 11. http://indiatoday.intoday.in/story/mayawati-government-uttarpradesh-luxury-statue-citizens-neglected/1/147733.html.

Iyer, Lakshmi, Tarun Khanna, and Ashutosh Varshney. 2013. "Caste and Entrepreneurship in India." Economic and Political Weekly 48 (6). Economic and Political Weekly: 52-60.

Jackman, Mary R. 1994. The Velvet Glove: Paternalism and Conflict in Gender, Class, and Race Relations. University of California Press.

Jaffrelot, Christophe. 2003. India's Silent Revolution: The Rise of the Lower Castes in North India. New York: Columbia University Press.

Jaffrelot, Christophe, and Sanjay Kumar, eds. 2009. Rise of the Plebeians?: The Changing Face of the Indian Legislative Assemblies. New Delhi; Abingdon; New York: Routledge.

Jeffrey, Robin. 1976. The Decline of Nair Dominance: Society and Politics in Travancore 1847-1908. Manohar.

Jensenius, Francesca. 2017. Social Justice Through Inclusion: The Consequences of Electoral Quotas in India. Oxford University Press.

Jost, John T., Mahzarin R. Banaji, and Brian A. Nosek. 2004. "A Decade of System Justification Theory: Accumulated Evidence of Conscious and Unconscious Bolstering of the Status Quo." Political Psychology 25 (6): 881-919.

Katznelson, Ira. 2005. When Affirmative Action Was White: An Untold History of Racial Inequality in Twentieth-Century America. W. W. Norton \& Company.

Keefer, Philip, and Stuti Khemani. 2003. "Democracy, Public Expenditures and the Poor." World Bank Policy Research Working Paper 3164. Washington DC: The World Bank.

Khanna, Gaurav. 2020. "Does Affirmative Action Incentivize Schooling? Evidence from India." The Review of Economics and Statistics 102 (2): 219-33.

Khemani, Stuti. 2003. "Partisan Politics and Intergovernmental Transfers in India." World Bank Policy Research Working Paper 3016. Washington DC: World Bank.

Kohli, Atul. 1987. The State and Poverty in India. Cambridge University Press.

- - . 2012. Poverty amid Plenty in the New India. Cambridge; New York: Cambridge University Press.

Kothari, Rajni. 1971. "The Political Change of 1967." Economic and Political Weekly 6 (3/5): 231-50.

Krishna, Anirudh. 2002. Active Social Capital: Tracing the Roots of Development and Democracy. Columbia University Press.

Kruks-Wisner, Gabrielle. 2018. "The Pursuit of Social Welfare: Citizen Claim-Making in Rural India." World Politics 70 (1): 122-63.

Kustov, Alexander, and Giuliana Pardelli. 2018. "Ethnoracial Homogeneity and Public Outcomes: The (Non)Effects of Diversity." American Political Science Review, June, 1-8. doi:10.1017/S0003055418000308.

Lipset, Seymour Martin. 1959. "Some Social Requisites of Democracy: Economic Development and Political Legitimacy." American Sociological Review 53 (1): 69-105. 
Lupu, Noam, and Jonas Pontusson. 2011. "The Structure of Inequality and the Politics of Redistribution." American Political Science Review 105 (2): 316-36.

Malik, Mashail. 2019. "Discrimination and Defiant Pride: How the Demand for Dignity Creates Slack for Poor Governance." Working Paper. Stanford University.

Mann, Michael. 1984. "The Autonomous Power of the State: Its Origins, Mechanisms and Results." European Journal of Sociology / Archives Européennes de Sociologie / Europäisches Archiv Für Soziologie 25 (2): 185-213.

Mansbridge, Jane. 1999. "Should Blacks Represent Blacks and Women Represent Women? A Contingent 'Yes.'" The Journal of Politics 61 (3): 628-57.

Mathew, George. 1982. Communal Road to a Secular Kerala. Concept Publishing Company.

Mathew, Santhosh, and Mick Moore. 2011. "State Incapacity by Design: Understanding the Bihar Story." IDS Working Papers 2011 (366): 1-31.

Mehta, Pratap Bhanu. 2003. The Burden of Democracy. Delhi: Penguin India.

Miguel, Edward, and Mary Kay Gugerty. 2005. "Ethnic Diversity, Social Sanctions, and Public Goods in Kenya." Journal of Public Economics 89 (11-12): 2325-68.

Mosse, David. 2018. "Caste and Development: Contemporary Perspectives on a Structure of Discrimination and Advantage." World Development 110 (October): 422-36.

Murali, Kanta. 2017. Caste, Class and Capital. Cambridge University Press.

Mutz, Diana C. 2018. "Status Threat, Not Economic Hardship, Explains the 2016 Presidential Vote." Proceedings of the National Academy of Sciences 115 (19): E4330-39.

Obama, Barack. 2006. The Audacity of Hope: Thoughts on Reclaiming the American Dream. Crown.

Ouwerkerk, Louise. 1994. No Elephants for the Maharaja: Social and Political Change in the Princely State of Travancore, (1921-1947). Manohar Publishers \& Distributors.

Paluck, Elizabeth Levy, Seth A. Green, and Donald P. Green. 2019. "The Contact Hypothesis Re-Evaluated." Behavioural Public Policy 3 (2). Cambridge University Press: 129-58.

Pande, Rohini. 2003. "Can Mandated Political Representation Increase Policy Influence for Disadvantaged Minorities? Theory and Evidence from India." The American Economic Review 93 (4): 1132-51.

Paul, Gilles Saint, and Thierry Verdier. 1996. "Inequality, Redistribution and Growth: A Challenge to the Conventional Political Economy Approach." European Economic Review, Papers and Proceedings of the Tenth Annual Congress of the European Economic Association, 40 (3-5): 719-28.

Pitkin, Hanna F. 1967. The Concept of Representation. University of California Press.

Przeworski, Adam, and Fernando Limongi. 1997. "Modernization: Theories and Facts." World Politics 49 (02): 155-183.

Putnam, Robert D, Robert Leonardi, and Raffaella Nanetti. 1993. Making Democracy Work: Civic Traditions in Modern Italy. Princeton, N.J.: Princeton University Press.

Quadagno, Jill S. 1994. The Color of Welfare: How Racism Undermined the War on Poverty. Oxford University Press.

Radhakrishnan, P. 1990. "Backward Classes in Tamil Nadu: 1872-1988." Economic and Political Weekly XXV (10): 509-520.

Rao, Vijayendra, and Paromita Sanyal. 2010. "Dignity through Discourse: Poverty and the Culture of Deliberation in Indian Village Democracies." The ANNALS of the American Academy of Political and Social Science 629 (1): 146-72.

Ravallion, Martin, and Gaurav Datt. 2002. "Why Has Economic Growth Been More Pro-Poor in Some States of India Than Others?" Journal of Development Economics 68 (2): 381-400.

Ridgeway, Cecilia L. 2014. "Why Status Matters for Inequality." American Sociological Review 79 (1): 1-16.

- - - 2019. Status: Why Is It Everywhere? Why Does It Matter? 1 edition. New York, New York: Russell Sage Foundation. 
Rodden, Jonathan, and Steven Wilkinson. 2004. "The Shifting Political Economy of Redistribution in the Indian Federation." In . Tucson, AZ.

Rudolph, Lloyd I., and Susanne Hoeber Rudolph. 1984. The Modernity of Tradition: Political Development in India. University of Chicago Press.

Rueschemeyer, Dietrich, Evelyne Huber, and John D Stephens. 1992. Capitalist Development and Democracy. Chicago: University of Chicago Press.

Sandbrook, Richard, Marc Edelman, Patrick Heller, and Judith Teichman. 2007. Social Democracy in the Global Periphery: Origins, Challenges, Prospects. Cambridge, UK ; New York: Cambridge University Press.

Sidanius, Jim, and Felicia Pratto. 1999. Social Dominance: An Intergroup Theory of Social Hierarchy and Oppression. Cambridge, UK ; New York: Cambridge University Press.

Singh, Prerna. 2016. How Solidarity Works for Welfare: Subnationalism and Social Development in India. New York, NY: Cambridge University Press.

Singh, Prerna, and Matthias vom Hau. 2016. "Ethnicity in Time: Politics, History, and the Relationship between Ethnic Diversity and Public Goods Provision." Comparative Political Studies 49 (10): 130340.

Sniderman, Paul M., and Thomas Leonard Piazza. 1993. The Scar of Race. Harvard University Press.

Soifer, Hillel. 2008. "State Infrastructural Power: Approaches to Conceptualization and Measurement." Studies in Comparative International Development 43 (3-4): 231-51.

Soss, Joe, and Vesla Weaver. 2017. "Police Are Our Government: Politics, Political Science, and the Policing of Race-Class Subjugated Communities." Annual Review of Political Science 20 (1): 565-91.

Srinivas, M. N. 1995. Social Change in Modern India. New Delhi: Orient BlackSwan.

Subramanian, Narendra. 2000. Ethnicity and Populist Mobilization: Political Parties, Citizens and Democracy in South India. Delhi: Oxford University Press.

Suryanarayan, Pavithra. 2017. "Hollowing Out the State: Franchise Expansion and Fiscal Capacity in Colonial India." SSRN Electronic Journal.

- - - 2018. "When Do the Poor Vote for the Right Wing and Why: Status Hierarchy and Vote Choice in the Indian States." Comparative Political Studies, May, 0010414018758752.

Suryanarayan, Pavithra, and Steven White. 2019. "Slavery, Reconstruction, and Bureaucratic Capacity in the American South." SSRN Electronic Journal.

Taylor, Charles. 1994. "The Politics of Recognition." In Multiculturalism: Examing the Politics of Recognition, edited by Charles Taylor and Amy Gutmann. Princeton, NJ: Princeton University Press.

Thachil, Tariq, and Emmanuel Teitelbaum. 2015. "Ethnic Parties and Public Spending New Theory and Evidence From the Indian States." Comparative Political Studies, 0010414015576743.

Thorat, Amit, and Omkar Joshi. 2015. "The Continuing Practice of Untouchability in India: Patterns and Mitigating Influences." India Human Development Study Working Paper 3.

Tsai, Lily L. 2007. "Solidarity Groups, Informal Accountability, and Local Public Goods Provision in Rural China." American Political Science Review 101 (2): 355-372.

Van Cott, Donna Lee. 2005. From Movements to Parties in Latin America: The Evolution of Ethnic Politics. Cambridge: Cambridge University Press.

Varshney, Ashutosh. 2000. "Is India Becoming More Democratic?" The Journal of Asian Studies 59 (1): 325.

Weber, Max. 1978. Economy and Society: An Outline of Interpretive Sociology. University of California Press.

Weiner, Myron. 1991. The Child and the State in India: Child Labor and Education Policy in Comparative Perspective. Princeton, N.J.: Princeton University Press.

- - . 2001. "The Struggle for Equality: Caste in Indian Politics." In The Success of India's Democracy, edited by Atul Kohli, 193-225. Cambridge; New York: Cambridge University Press. 
Wilson, Sven E., and Daniel M. Butler. 2007. "A Lot More to Do: The Sensitivity of Time-Series Cross-Section Analyses to Simple Alternative Specifications." Political Analysis 15 (2): 101-23. doi:10.1093/pan/mpl012.

Wimmer, Andreas. 2002. Nationalist Exclusion and Ethnic Conflict: Shadows of Modernity. Cambridge University Press.

- - . 2015. "Is Diversity Detrimental? Ethnic Fractionalization, Public Goods Provision, and the Historical Legacies of Stateness." Comparative Political Studies, 0010414015592645.

Wimmer, Andreas, Lars-Erik Cederman, and Brian Min. 2009. "Ethnic Politics and Armed Conflict: A Configurational Analysis of a New Global Data Set." American Sociological Review 74 (2). SAGE Publications Inc: 316-37.

Witsoe, Jeffrey. 2013. Democracy against Development: Lower-Caste Politics and Political Modernity in Postcolonial India. Chicago ; London: University Of Chicago Press.

Yadav, Yogendra. 2000. "Understanding the Second Democratic Upsurge: Trends of Bahujan Participation in Electoral Politics in the 1990s." In Transforming India, edited by Francine R Frankel, Zoya Hasan, Rajeev Bhargava, and Balveer Arora. Delhi: Oxford University Press.

- - . 2010. "What Is Living and What Is Dead in Rammanohar Lohia?" Economic and Political Weekly 45 (40): 92-107. 